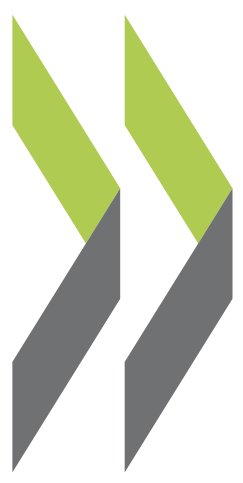

OECD Economics Department Working Papers No. 1164

Addressing High Household Debt in Korea
Randall S. Jones,

Myungkyoo Kim 
Organisation de Coopération et de Développement Économiques

Organisation for Economic Co-operation and Development

16-Sep-2014

ECONOMICS DEPARTMENT

English - Or. English

ADDRESSING HIGH HOUSEHOLD DEBT IN KOREA

ECONOMICS DEPARTMENT WORKING PAPERS No. 1164

By Randall S. Jones and Myungkyoo Kim

OECD Working Papers should not be reported as representing the official views of the OECD or of its member countries. The opinions expressed and arguments employed are those of the author(s).

Authorised for publication by Alvaro Pereira, Director, Country Studies Branch, Economics Department.

All Economics Department Working Papers are available through OECD's Internet website at http://www.oecd.org/eco/workingpapers

Complete document available on OLIS in its original format

This document and any map included herein are without prejudice to the status of or sovereignty over any territory, to the delimitation of international frontiers and boundaries and to the name of any territory, city or area. 
OECD Working Papers should not be reported as representing the official views of the OECD or of its member countries. The opinions expressed and arguments employed are those of the author(s).

Working Papers describe preliminary results or research in progress by the author(s) and are published to stimulate discussion on a broad range of issues on which the OECD works.

Comments on Working Papers are welcomed, and may be sent to the Economics Department, OECD, 2 rue André-Pascal, 75775 Paris Cedex 16, France, or by e-mail to eco.contact@oecd.org.

This document and any map included herein are without prejudice to the status of or sovereignty over any territory, to the delimitation of international frontiers and boundaries and to the name of any territory, city or area.

The statistical data for Israel are supplied by and under the responsibility of the relevant Israeli authorities. The use of such data by the OECD is without prejudice to the status of the Golan Heights, East Jerusalem and Israeli settlements in the West Bank under the terms of international law.

\section{(C) OECD (2014)}

You can copy, download or print OECD content for your own use, and you can include excerpts from OECD publications, databases and multimedia products in your own documents, presentations, blogs, websites and teaching materials, provided that suitable acknowledgment of OECD as source and copyright owner is given. All requests for commercial use and translation rights should be submitted to rights@oecd.org 
ECO/WKP(2014)60

\section{ABSTRACT/RÉSUMÉ}

\section{Addressing high household debt in Korea}

Rising household debt has become a major policy concern in Korea. By the end of 2012, it had risen to $164 \%$ of disposable income, well above the OECD average of $133 \%$. In addition to the economic impact and the risk to the financial sector, it raises social cohesion issues, as households with low income and credit ratings have limited access to financial markets and many are delinquent on their loans. It is essential to induce the soft-landing of household debt through a two-track approach: $i$ ) offering credit to households with low income and credit ratings and restructuring their debt, while limiting moral hazard and developing market-based lending; and ii) containing the risk caused by high household debt by strengthening prudential measures for financial institutions and improving mortgage lending by reducing the share of floating-rate and "bullet repayment" loans.

This Working Paper relates to the 2014 OECD Economic Survey of Korea (www.oecd.org/eco/surveys/economic-survey-korea.htm)

JEL classification: D14, D91, G21.

Keywords: household debt, banks, consumer finance companies, mortgages, bullet loans, debt restructuring, delinquent borrowers, individual workouts, individual bankruptcy, National Happiness Fund, Miso Finance, Sunshine Loans, New Hope Seed Loans

$* * * * * * * * * * * * * * * * * * * * * * * * * * * * * *$

\section{Comment faire face au fort endettement des ménages en Corée}

L'endettement croissant des ménages est l'un des grands sujets de préoccupation des pouvoirs publics en Corée. Fin 2012, il se montait à $164 \%$ du revenu disponible des ménages, nettement au-dessus de la moyenne OCDE de $133 \%$. Outre ses conséquences économiques et les risques pour le secteur financier, il soulève des questions sur la cohésion sociale, car les ménages les plus modestes et les moins solvables n'ont guère accès au marché du crédit et leurs taux de défaillance sont élevés. Il convient de favoriser un retour ordonné à un niveau d'endettement plus faible pour les ménages en agissant sur deux leviers : $i$ ) en offrant des crédits aux ménages les plus modestes et les moins solvables et en restructurant leur dette, tout en limitant l'aléa moral et en développant le recours aux mécanismes du marché dans l'activité de prêt; et ii) en contenant le risque causé par l'endettement élevé des ménages par le renforcement des mesures prudentielles pour les institutions financières et en améliorant les prêts hypothécaires par la réduction de la part des prêts à taux variables ou à « remboursement in fine ».

Ce Document de travail a trait à l'Étude économique de l'OCDE de la Corée, 2014

(www.oecd.org/fr/eco/etudes/coree.htm).

Classification JEL : D14, D91, G21.

Mots clés : endettement des ménages, banques, sociétés de crédit à la consommation, prêts hypothécaires, préts à remboursement in fine, restructuration des dettes, emprunteurs défaillants, négociations individuelles, faillite individuelle, Fond National du Bonheur, Miso Finance. 


\section{TABLE OF CONTENTS}

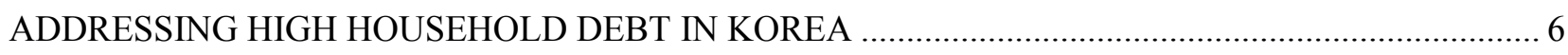

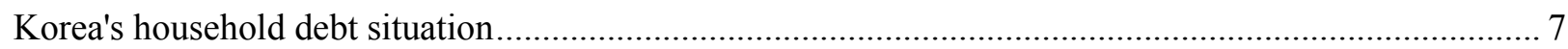

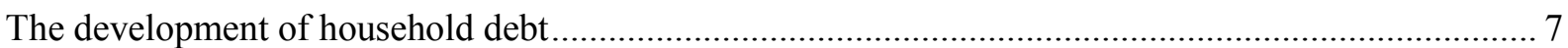

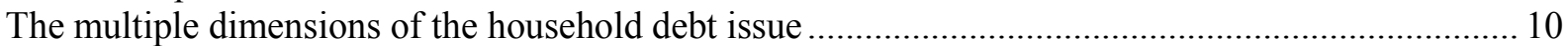

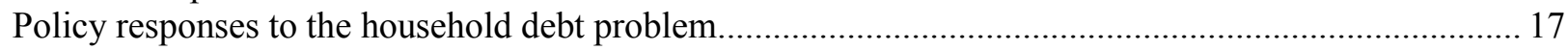

Strengthening support for people with low income and credit ratings ............................................. 18

Containing the growth of household debt and removing potential risk factors within household debt. 20

Impact of recent policies and measures needed to address remaining challenges .................................. 24

Although household debt accumulation has slowed, its ratio to disposable income is still rising ........24

Reducing structural weaknesses in household debt ..........................................................................25

Limiting the risks posed by household debt for financial institutions ................................................ 29

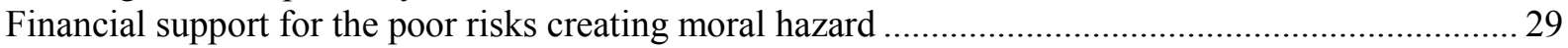

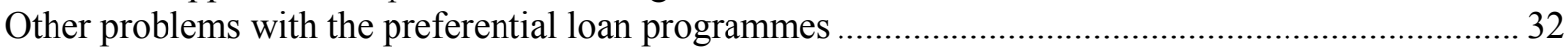

Promoting responsible lending by financial institutions and financial education for consumers.......... 33

\section{Tables}

1. The impact of economic shocks on the banking system .............................................................. 14

2. The share of household lending by type of financial institution varies based on credit ratings............ 16

3. Interest rates on loans to households vary widely by type of lender.................................................... 17

4. Preferential loans to people with low income and credit ratings..................................................... 19

5. The development of credit recovery support programmes for delinquent borrowers ........................... 20

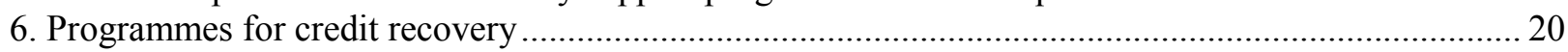

7. Debt restructuring process under the National Happiness Fund ……............................................. 22

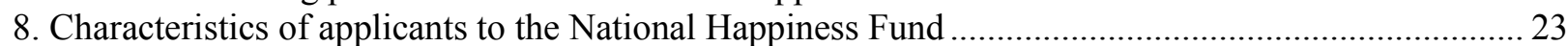

9. The share of fixed rate and instalment repayment mortgage loans of banks ...................................... 24

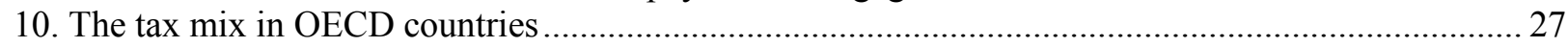

11. Government support in the four major preferential loan programmes ............................................. 30

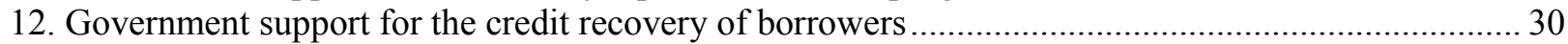

\section{Figures}

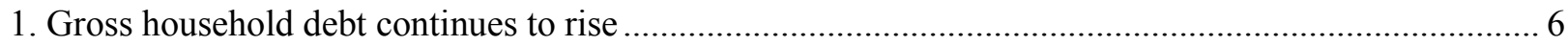

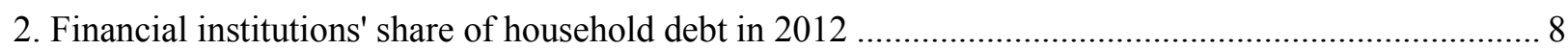

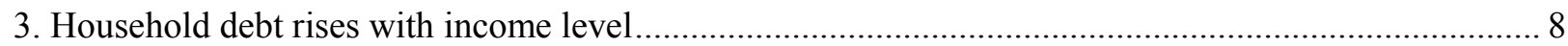

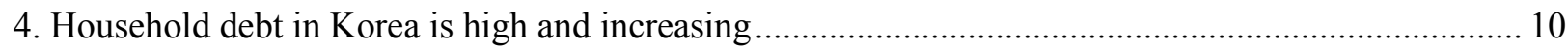

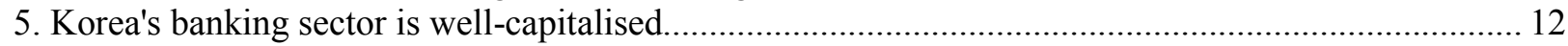

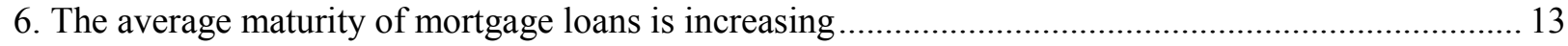

7. Private consumption growth has lagged behind GDP growth...................................................... 15

8. The share of loans given to individuals with low credit ratings is falling .......................................... 16

9. The number of borrowers listed as delinquent has declined .......................................................... 17

10. Non-bank financial institutions account for most of the growth in household debt............................ 23

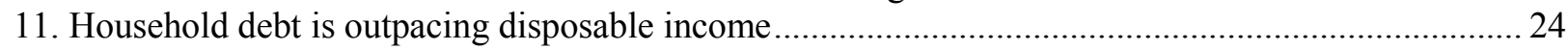

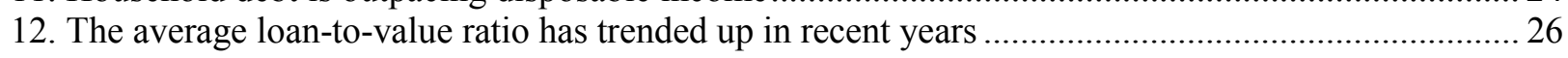

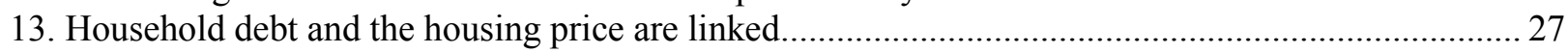

14. The debt of borrowers with multiple loans is increasing ............................................................... 28 


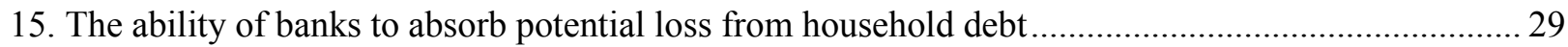

16. The delinquency rate of preferential loan programmes is rising ....................................................... 31

\section{Boxes}

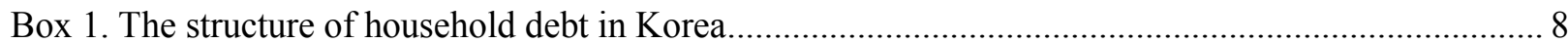

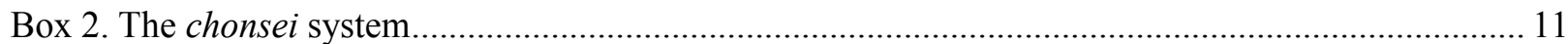

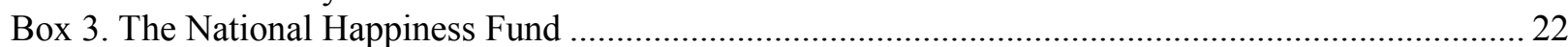

Box 4. Summary of recommendations to address the household debt problem...................................... 34 


\title{
ADDRESSING HIGH HOUSEHOLD DEBT IN KOREA
}

\author{
By Randall S. Jones and Myungkyoo Kim ${ }^{l}$
}

1. Household debt has become a major policy concern in Korea since the global financial crisis. Debt reached $146 \%$ of household disposable income at the end of 2007 (Figure 1), matching that in the United States. Nevertheless, the high debt level did not cause any significant financial market turbulence. Korea's 2008 financial-sector crisis was instead due to capital outflows (2012 OECD Economic Survey of Korea). Following the crisis, the household debt ratio increased further to $164 \%$ at the end of 2012, well above the OECD average of $133 \%$. Containing the risk generated by increasing household debt and its impact on economic growth has become an important government priority.

Figure 1. Gross household debt continues to rise

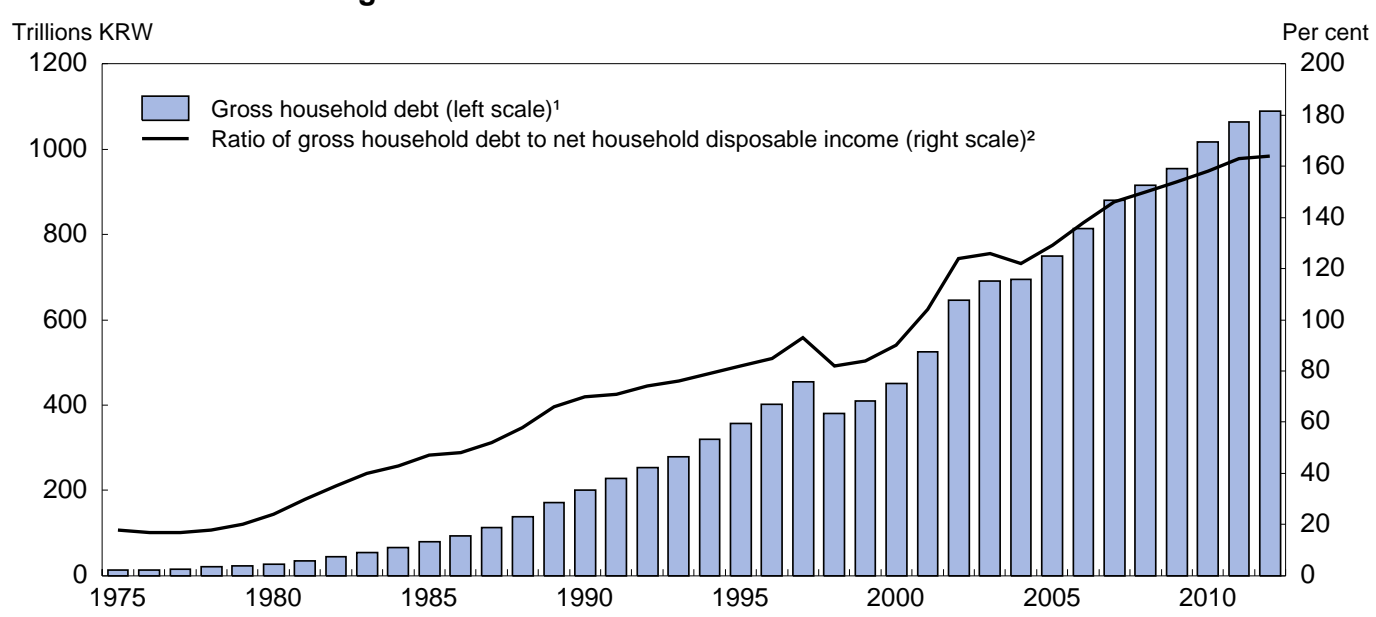

1. In real terms, adjusted by the $2010 \mathrm{CPI}$.

2. In current prices.

Source: Bank of Korea.

2. As its debt rises, the household sector becomes increasingly sensitive to shocks to income and interest rates, thus amplifying the impact of such shocks (Debelle, 2004). This is true regardless of whether the debt is sustainable. Higher debt also forces households to modify their consumption and investment, thus increasing the risk of a significant economic downturn (OECD, 2012a). In addition, when rising household debt is connected with housing bubbles, such as in the 2008 global financial crisis, the output contraction is larger and the recovery slower (IMF, 2012). For these reasons, it is crucial to prevent excessive household debt accumulation and to respond quickly before it becomes a serious headwind to growth and a risk to financial markets.

1. Randall S. Jones is head of the Japan/Korea Desk in the Economics Department of the OECD and Myungkyoo Kim is an economist on that Desk. This paper is based on material prepared for the $O E C D$ Economic Survey of Korea published in June 2014 under the authority of the Economic and Development Review Committee (EDRC). The authors would like to thank Christophe André, Romain Bouis, Andrew Dean, Robert Ford, Vincent Koen, and Satoshi Urasawa for valuable comments on earlier drafts. Special thanks go to Lutécia Daniel for technical assistance and to Nadine Dufour and Mikel Inarritu for technical preparation. 
3. Addressing the household debt problem is also critical for social cohesion in Korea. The run-up in debt has made financial institutions increasingly reluctant to lend to households, particularly those with low incomes and credit ratings, at the same time as the financial needs of such households are increasing due to weak economic growth. Ensuring sufficient credit and financial services to such households is a major concern. In addition, a large number of households have been unable to service their debt. If they were to remain excluded from financial markets, the delinquent borrowers would lose the opportunity to improve their economic condition, thereby widening income inequality.

4. The government has taken a range of policy measures since 2008 to address the multiple dimensions of household debt. On one hand, it has focused on facilitating credit supply to people with low income and little access to credit who are vulnerable to weak economic conditions. In addition, the government has expanded support for delinquent borrowers, notably through the National Happiness Fund. Another priority has been to contain the growth of household debt and to reduce the risks attached to it. In particular, the government has taken measures to address risks in the mortgage loan market, which accounts for about one-half of household debt. Despite such measures, the household debt ratio continues to rise and a sizable number of households with low income and credit ratings still have difficulty in accessing credit at affordable rates.

5. This paper begins with an overview of the development of household debt since the 1997 crisis and its implications for the economy and social cohesion. The following sections analyse government programmes to address the debt issue and then considers their impact, as well as remaining policy challenges. Policy recommendations are summarised in Box 4.

\section{Korea's household debt situation}

\section{The development of household debt}

6. Korea's household debt ratio was below 20\% prior to 1978 (Figure 1), as the government funnelled savings to the industrial sector to finance export-led growth. However, the ratio has increased steadily since then, except in 1998 in the wake of the Asian financial crisis and in 2004 following the collapse of the credit card bubble. The 1997 crisis led to large-scale delinquency of corporate loans and the failure of a large number of financial institutions. Those that survived changed their business model by reducing lending to large companies, recognising that the "too-big-to-fail" model was no longer valid. Consequently, financial institutions' survival could be threatened by the default of a few large firms. The change in bank behaviour was accompanied by a fall in corporate demand for loans as they paid increased attention to balance-sheet risks and shifted their focus from size to profitability. As a result, the debt-toequity ratio of manufacturing companies fell from 396\% at the end of 1997 to $135 \%$ at the end of 2012 . Meanwhile, financial institutions increased their lending to households, as well as to small and mediumsized enterprises (SMEs), to compensate for the decline in loans to large companies. Indeed, loans to households increased from $30 \%$ of banks' total lending in 1997 to $50 \%$ in $2002 .^{2}$ In 2012, deposit-taking banks held a little more than half of household debt (Box 1).

2. Commercial banks' lending to households increased at an annual rate of over $40 \%$ during $1999-2002$, well above the $15 \%$ rate for lending to corporations (FSC and FSS, 2011). 


\section{Box 1. The structure of household debt in Korea}

In Korea, there are two major sources of information on household debt: flow-of-funds data and "household credit" compiled by the Bank of Korea since the early 2000s. The latter excludes some debt, such as loans to nonprofit organisations and individual entrepreneurs, which is not directly related with household debt. The flow-of-funds figure, which is used for international comparisons, does include lending for individual entrepreneurs in the case of Korea.

According to the household credit statistics, household debt (as a share of household disposable income) rose by 22 percentage points during the decade to 2012, compared to 40 points based on the flow of funds data. By 2012, it had reached 959 trillion KRW, $136 \%$ of household disposable income, well below the $164 \%$ based on flow of funds data. Of the total, 901 trillion KRW is household loans, while the remainder is credit generated by goods and services transactions through credit cards, leases and so on. A little more than half of household loans are for housing.

In terms of credit providers, deposit financial institutions, especially banks, are the most significant players. Banks held one-half of outstanding household loans in 2013, while other deposit-taking institutions accounted for another quarter (Figure 2). Finally, non-deposit financial institutions, such as insurance and securities companies, together held another quarter. Looking at debtors by household income level, the top $40 \%$ of the income distribution accounted for $70 \%$ of total household debt in 2012 , while the bottom $40 \%$ accounted for only $16 \%$ (Figure 3 ).

Figure 2. Financial institutions' share of household debt in 2013

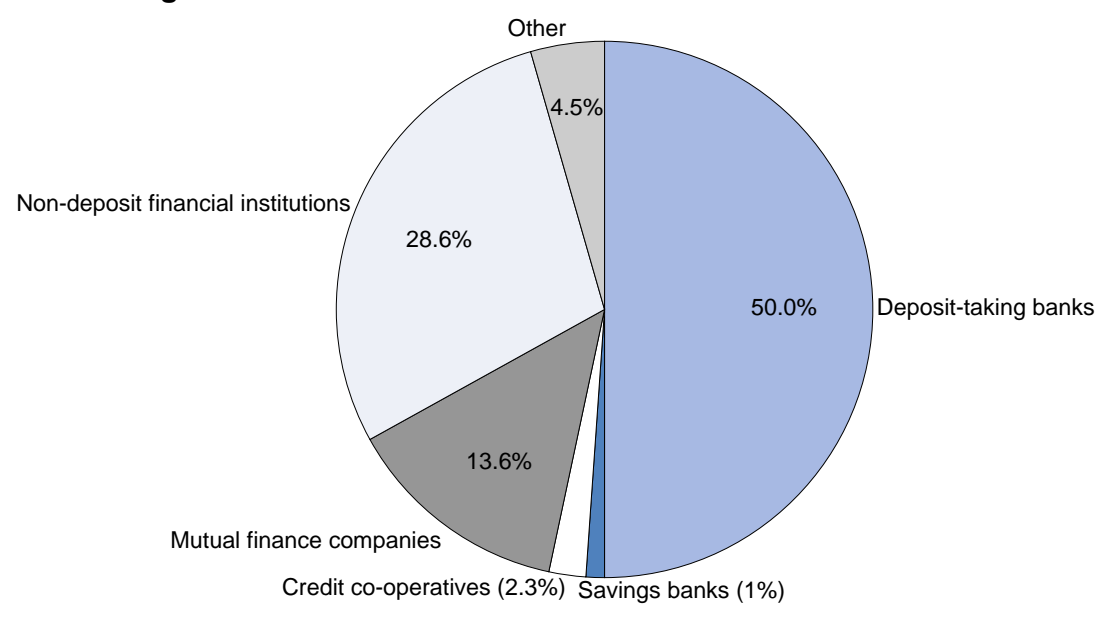

Source: Bank of Korea (2013b).

Figure 3. Household debt rises with income levels Income quintiles in 2012

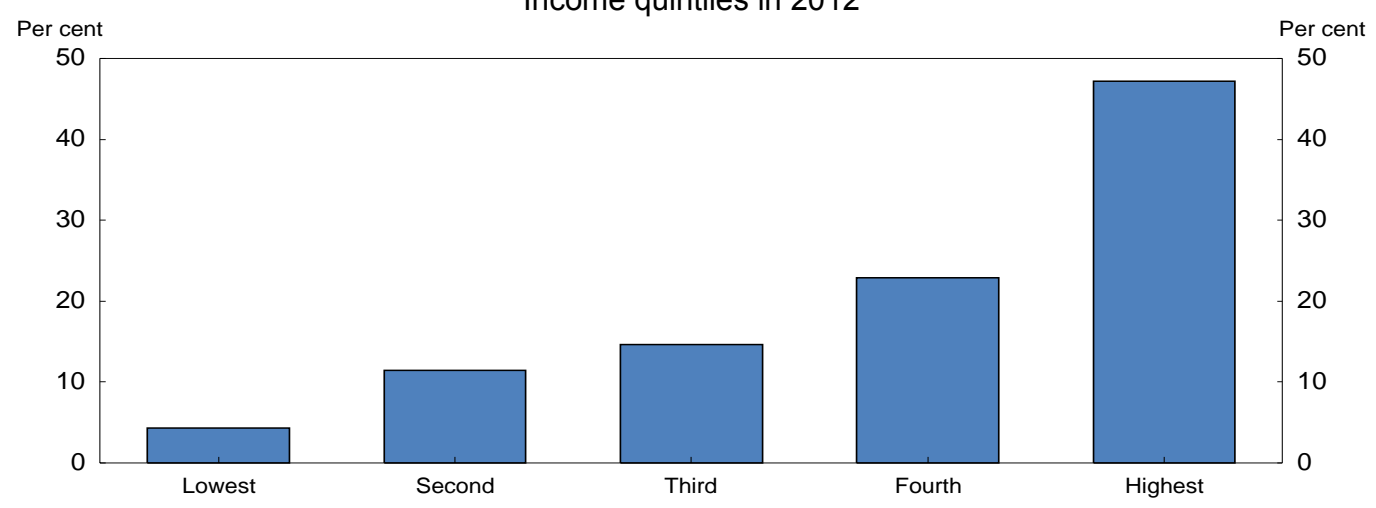

Source: Statistics Korea et al. (2013). 
7. Other factors also pushed up the household debt ratio following the 1997 crisis. First, the government introduced tax measures in 1998 to encourage the use of credit cards with the aim of enhancing transparency about the income of the self-employed and reducing tax evasion. Indeed, the use of credit cards expanded 11-fold between 1998 and 2002. Consequently, credit cards accounted for much of the increase in household debt, growing 30\% each year over 1998-2002. Second, the Bank of Korea pursued a very accommodative monetary policy following the severe 1998 recession, while the government boosted the economy with tax incentives and regulatory reform (2001 OECD Economic Survey of Korea).

8. However, the rapid growth of household debt, especially through credit cards, ended in 2004. A significant share of credit card loans had been made without proper credit evaluation, driven by the strong marketing drive of credit card companies to attract new customers (KIF, 2013). In addition, the infrastructure of the household debt market was underdeveloped. Although commercial banks began to establish credit evaluation procedures for household loans around the time of the 1997 crisis, it was difficult for them to check the credit rating and existing debt of potential borrowers. Credit evaluation models based on the historical credit record of individual debtors did not exist until 2004. Moreover, the limited information that was available was not shared among financial institutions (KIF, 2013).

9. These factors triggered a surge in defaults on credit card loans and a collapse of the credit card bubble. The loans had been made by banks and financial companies specialising in the credit card business. While banks could finance such lending through deposits, the credit card companies raise funds through bond issuance or borrowing from other financial institutions, making them more vulnerable to financial conditions. As financing through corporate bonds became difficult and concern over potential bad loans spread, the credit card companies had to reduce their outstanding loans, leading to widespread defaults by individual credit card holders. Consequently, the household debt to disposable income ratio fell by 4.4 percentage points in 2004 (Figure 1).

10. However, the collapse of the bubble stimulated the development of the necessary infrastructure for the household debt market and laid the foundation for its continued growth. In particular, in 2005, financial institutions expanded information through the establishment of a credit bureau, which collects credit information on individual debtors and provides credit evaluations. The government also upgraded laws and regulations related to consumer finance. Financial consumer protection, including legal and financial support for the recovery of delinquent debt, was strengthened as well.

11. Although the household debt ratio in Korea in $2004(122 \%)$ already exceeded the $110 \%$ OECD average, it resumed its upward trend in 2005. The stock of gross debt continued to increase even after the 2008 crisis, although the growth rate slowed from $7-8 \%$ per year to $3-4 \%$. With an even larger deceleration in household disposable income, the household debt ratio rose further. Korea is not unique in this regard; the household debt ratio increased over 2007-12 in 19 of the 30 OECD countries for which data are available. ${ }^{3}$ Still, Korea stands out for two reasons. First, the level of household debt in 2007 was already high at $146 \%$ of household disposable income, compared to an OECD average of $127 \%$. Second, the rise in Korea was 18 percentage points, well above the OECD average of 6 points (Figure 4). Consequently, the gap between Korea's household debt ratio and the OECD average widened from 19 percentage points in $2007(146 \%$ versus $127 \%)$ to 31 points in 2012 (164\% versus 133\%) (Panel B). Korea's ratio was the eighth highest in the OECD area that year. Moreover, net household assets in Korea, at $187 \%$ of household disposable income in 2012, were below the OECD average of $212 \%$.

3. Of the eleven countries with a fall in the ratio, the decline exceeded 10 percentage points in only two countries: the United Kingdom (28 points) and the United States (29 points). 
Figure 4. Household debt in Korea is high and increasing A. Change in ratio of household debt to net household disposable income between 2007 and 2012

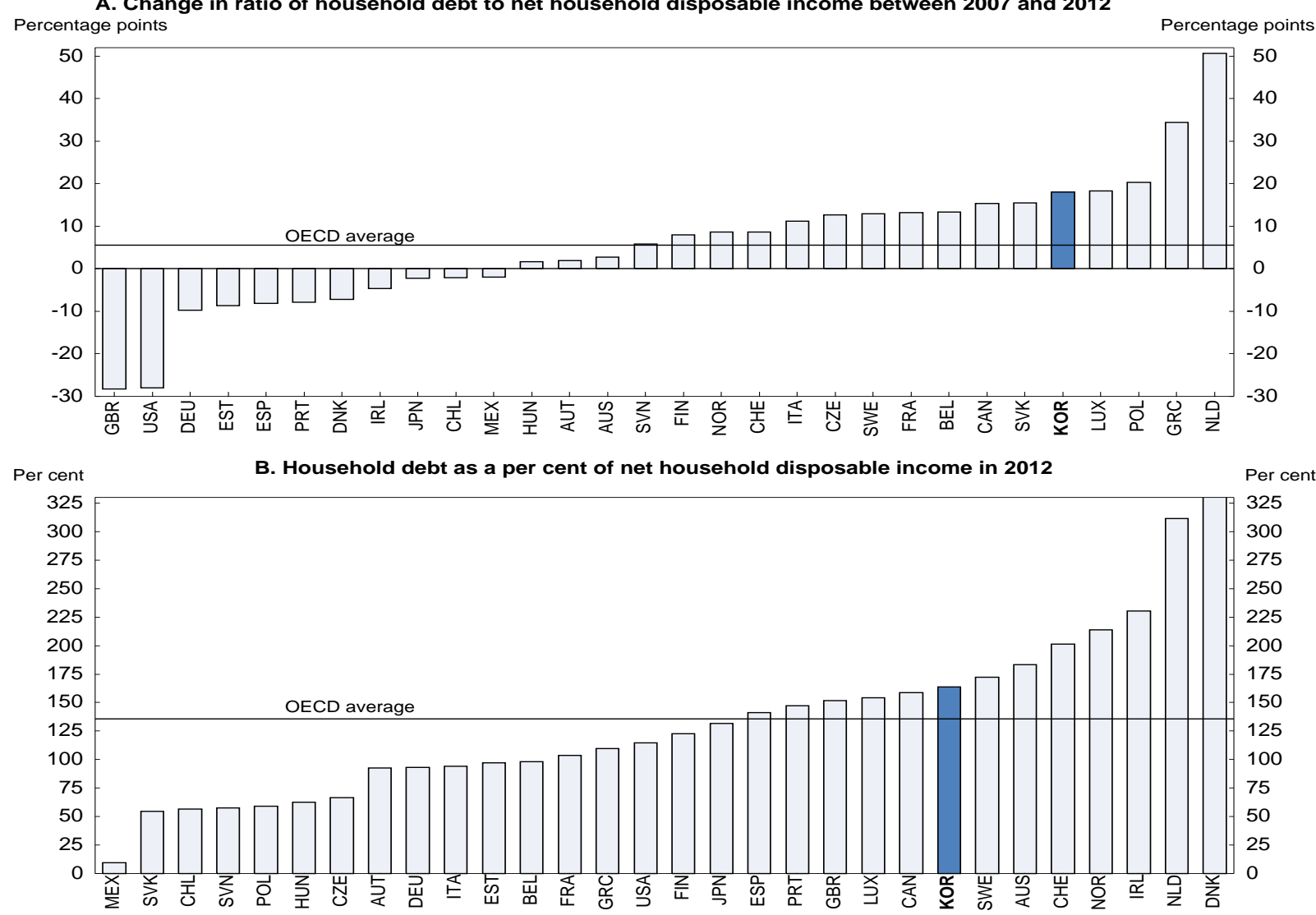

Source: National Accounts at a Glance Database.

12. The continued growth of household debt from its already high debt in 2004 reflects several factors. First, the development of the infrastructure for the household debt market noted above facilitated the growth of loans to households. Second, the 10\% rise in real housing prices over 2004-06 played a role, although real housing prices have fallen gradually since 2008. Third, the retirement of the baby boom generation (the 7 million people born between 1955 and 1963) from firms is increasing household borrowing. In Korea, employees leave firms at a relatively young age. Indeed, the mandatory retirement age set by firms in 2010 was 57 and many leave earlier as firms are anxious to push them out in the context of seniority-based wages (2012 OECD Economic Survey of Korea). To provide retirement income, departing employees often purchase small businesses, in part through borrowing.

\section{The multiple dimensions of the household debt issue}

13. Household debt is not only a financial issue, but also has economic and social dimensions. If there are large-scale defaults, the financial institutions that provided those loans could face solvency and liquidity difficulties that might lead to systemic problems in the financial market. In addition, the accumulation of household debt affects the pace of economic growth. Household debt also has a social dimension, as some low-income households depend on borrowing to fill the gap between income and expenditures. A survey of households with debt found that the major reasons for borrowing are: $i$ ) buying a house $(34.3 \%)$; ii) financing living costs $(25.4 \%)$; iii) renting a house, under a monthly rent system or the chonsei system (Box 2), which requires paying a lump sum up front (12.6\%); and iv) financing a business $(12.2 \%)(B O K, 2013 \mathrm{c})$. However, when borrowers fall into default, they are excluded from the regular financial market, which can exacerbate inequality and reduce access to opportunities. Measures to help defaulted borrowers recover their credit are thus an important aspect of promoting social cohesion. 
ECO/WKP(2014)60

\section{Box 2. The chonsei system}

The chonsei system, which has existed for more than a century, played a key role in Korea's rapid urbanisation since the 1960s, when capital was reserved for the industrial sector. With banks restricted from lending to developers, homeowners and tenants, the chonsei system provided a useful alternative. Under this system, a tenant deposits a lump sum for two years, instead of paying monthly rent, and the deposit - minus the interest earned by the owner - is refunded at the end of the contract. In other words, the owner grants the tenant the use of the residence for two years in exchange for a loan. The lump-sum deposit generally ranges from $40 \%$ to $70 \%$ of the price of the home, depending on market conditions. Landlords frequently use the chonsei deposit to invest in additional housing, which has been viewed as certain to rise in value at a faster pace than other assets, without relying on borrowing. It is estimated that about half of all chonsei money (about 300 trillion KRW or $25 \%$ of GDP) is used to finance a second or third property.

In 2010 , about $54 \%$ of households lived in owner-occupied housing. The share is limited by the mortgage system, as prospective buyers have to pay about $80 \%$ of the home price up front. Of the other $46 \%$ of households, about onehalf live in chonsei housing and the remainder in rental homes. The share living in chonsei housing is higher in Seoul $(33 \%)$, where housing is more expensive, than in the nation as a whole $(22 \%)$. Of the rental homes, most are "mixed chonsei", which requires that the tenant pay a combination of an upfront deposit and monthly rent. Consequently, only $4 \%$ of households nationwide live in purely rental housing, reflecting the government's emphasis on constructing owner-occupied housing rather than rental units (Kim, 2012).

The chonsei system was a market response to the difficulty of obtaining financing for purchasing housing due to "financial repression", which funneled savings to the industrial sector. The system has endured thanks to its advantages for both tenants and landlords:

- It allows those who do not own homes to obtain housing at a lower cost than paying monthly rent. Monthly rental has long been synonymous with poverty.

- The tenants' deposits over time become their own home-purchase fund.

- The landlord cannot terminate the tenancy, which is set at two years by law, without agreement from the tenants.

- For the landlord, the chonsei deposit facilitates the purchase of another house in the context where mortgage financing is not easy and housing prices are expected to rise continuously. Moreover, the landlord does not have to worry about the non-payment or late payment of monthly rent.

The chonsei system is sensitive to economic conditions. When house prices fall and interest rates are low, the ratio of the chonsei deposit to the house price rises, which may force tenants to borrow to pay the deposit. The continued existence of the system depends on the expectations that housing prices will continue rising, making homeowners anxious to leverage their existing properties through the chonsei system to purchase additional housing (Kim, 2012). With housing prices falling and interest rates low, an increasing share of landlords are demanding monthly rent payments or a hybrid system of monthly rent and deposits.

As the chonsei is considered an agreement between individuals, the deposits are still not included in Korea's household debt statistics or in loan-to-value (LTV) statistics. If added to housing loans, the average LTV ratio would rise from just under $50 \%$ (the regulated limit) to over $75 \%$. Last November, the Bank of Korea estimated that a tenth of Korea's 3.7 million chonsei landlords may find it hard to repay tenants' deposits (The Economist, 2014).

\section{Household debt as a potential risk for financial markets}

14. Since the credit card bubble burst in 2004, the delinquency ratio of household loans has remained low. The share of total substandard loans - interest or principal payments suspended for more than three months - has been steady at below $2 \%$ (Figure 5). The capacity of financial institutions to absorb potential losses seems sufficient, given their capital adequacy ratio of nearly $14 \%$. 
Figure 5. Korea's banking sector is well-capitalised

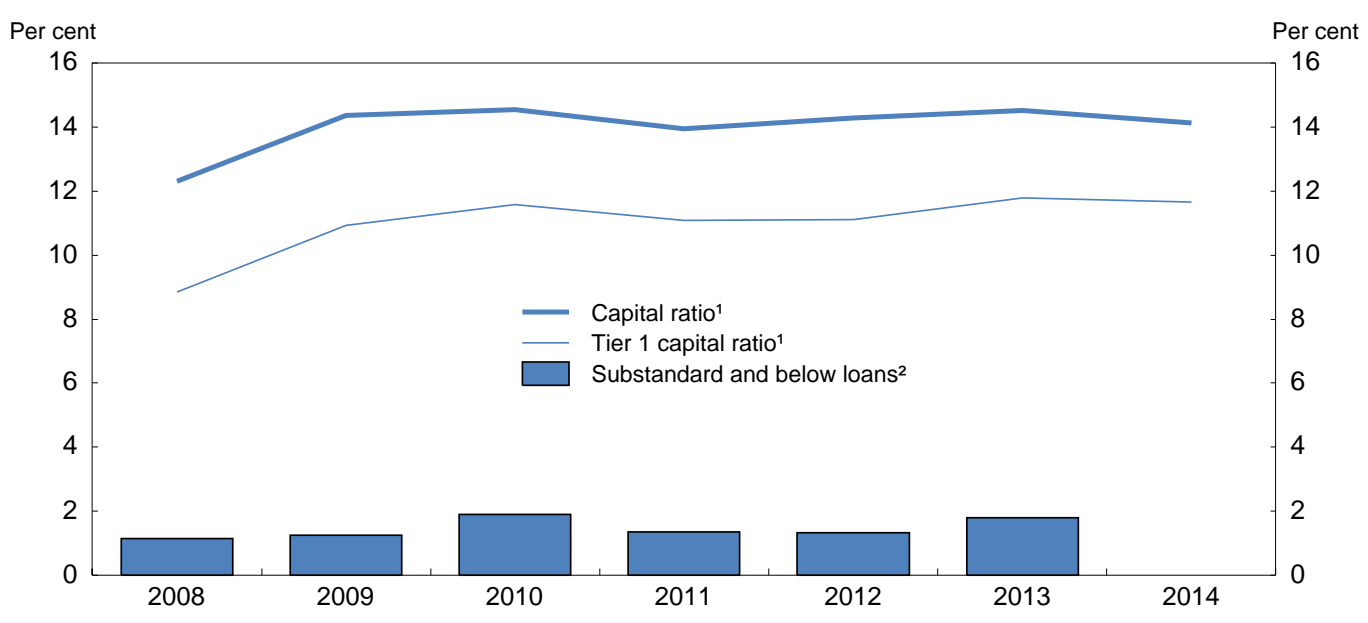

1. As a share of total risk-weighted assets. The figures for 2014 are for March.

2. Includes loans classified as substandard, doubtful and presumed loss as a share of total loans.

Source: Financial Supervisory Service (2013b and 2013c).

15. Nevertheless, there are potential risks, notably structural weaknesses in mortgage lending, that could threaten financial market soundness. Mortgage loans, which as noted above account for half of household credit, ${ }^{4}$ have vulnerabilities related to their maturity, repayment conditions and interest rate structure. First, $55 \%$ of mortgage loans carry a floating rate, linked to short-term interest rates, thus exposing households to interest rate risk. Second, of the 320 trillion KRW (25\% of GDP) of mortgage debt in June 2013, a quarter is due within three years (Chosun Ilbo, 2013). This suggests a much shorter maturity than in other OECD countries, where it ranges from 15 to 45 years. ${ }^{5}$ However, the average length of mortgage loans in Korea is increasing. In 2007, only two-fifths of mortgages had a remaining maturity of more than ten years, but by 2012, the share had risen to three-fifths (Figure 6). Meanwhile, the share with less than three years fell from $38 \%$ to $28 \%$.

16. Third, $30 \%$ of mortgages use a "bullet repayment" system, in which the borrower pays only interest during the term of the loan and pays off all of the principal when the loan reaches maturity. The remaining $70 \%$ of mortgage loans are referred to as "instalment loans". Around $60 \%$ of instalment loans (or about $40 \%$ of total mortgage loans) allow a grace period during which the borrower only has to pay interest. The purpose of such schemes is to reduce the burden on borrowers, which would be too heavy if they had to pay both principal and interest, given the short average maturity of loans. The large share of bullet mortgage loans and grace periods on paying principal are thus ways to cope with the short maturity of mortgages (KIF, 2013). However, this approach also has a negative aspect as the short maturity exposes households to turnover risk within a relatively short period, ${ }^{6}$ making them more vulnerable to the business

4. In order to examine the composition of household debt, the Bank of Korea's household credit statistics are used rather than the household debt data in the flow of funds statistics, which are used for international comparisons.

5. Compared to Korea, the usual maturity of mortgage loans is longer in France (15 20 years), Germany (20 30), the Netherlands (30), Spain and Switzerland (15 20), Sweden (30 45), the United States (30), Canada, Australia and the United Kingdom (25) and Japan (20 30) (KIF, 2013).

6. Around 80 trillion KRW of home mortgage loans in June 2013 will be due by June 2016. In addition, the grace period on 56 trillion KRW of instalment loans will also end within three years, requiring them to start paying principal (Chosun Ilbo, 29 August 2013). 
cycle. The risk is less during periods of rising house prices, which facilitates the roll-over of the mortgage or the sale of the home when the loan reaches maturity, thereby keeping default rates low.

\section{Figure 6. The average maturity of mortgage loans is increasing}

The distribution of banks' mortgage loans by the remaining maturity

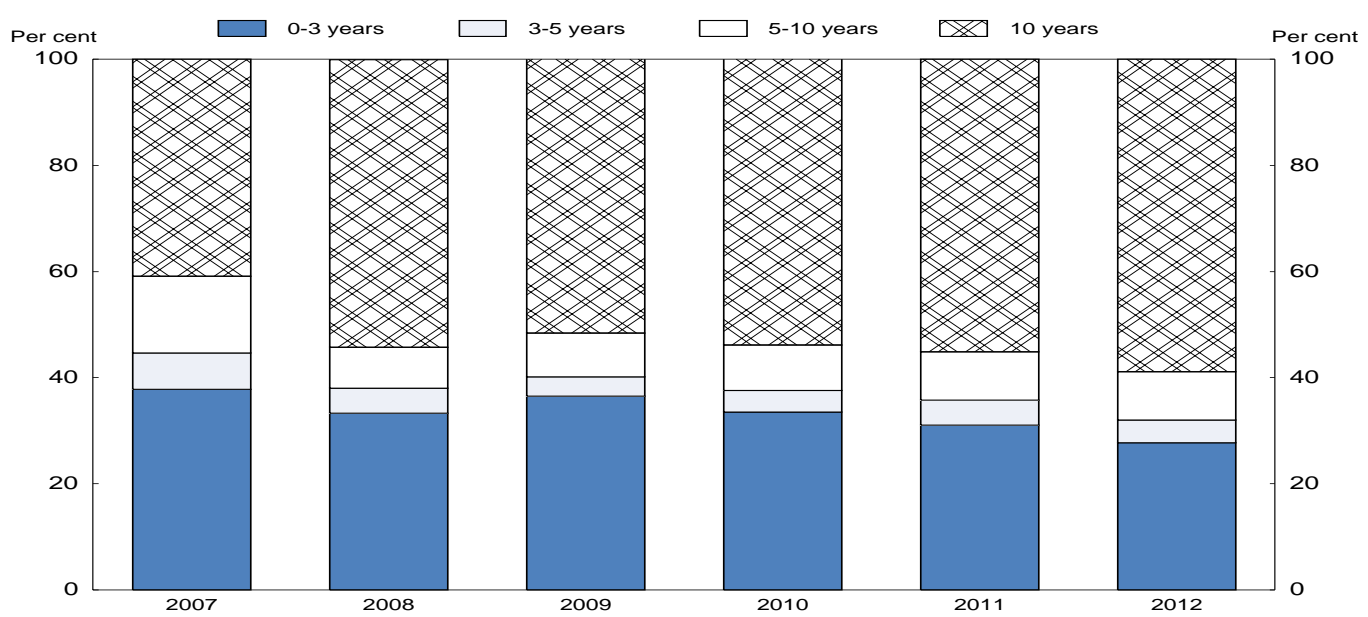

Source: Shin (2013).

17. However, if economic conditions become unfavourable, financial institutions hesitate to roll over mortgages, forcing borrowers to sell their homes to pay off the loan when it comes due. The sale of houses at fire-sale prices puts further downward pressure on housing prices, exacerbating the situation and leading to defaults. Consequently, a mortgage market characterised by short maturities and bullet repayments is more vulnerable to housing market shocks compared to a system based on longer-term loans (KIF, 2013). To cope with the risk of default, the government tightened regulations on housing loans. Loan-to-value (LTV) regulations were made explicit, initially at $60 \%$ and later lowered to $40 \%$ in "speculative zones", primarily in Seoul where housing prices showed the largest increases, reinforcing the need for large down payments. At present, the ceiling on the LTV ratio in the Seoul metropolitan area is set at $50 \%$ for houses costing more than 600 million KRW (around \$578 thousand) and 60\% for houses below that threshold. In the rest of the country, the LTV is set at $60 \%$. The LTV ceilings are relatively low compared to those in many OECD countries (2007 OECD Economic Survey of Korea). In 2005, the government introduced debt-to-income (DTI) regulations. In the case of homes priced above 600 million KRW in the speculative zones, the DTI is limited to $40 \%$.

18. Even with these structural weaknesses, however, bank reserves at present appear to be sufficient to cope with potential losses generated by household debt. According to a study by the Korea Institute of Finance (KIF), a research institution funded by banks, a $20 \%$ drop in the price of residential real estate would reduce banks' capital adequacy ratio by only 1.1 percentage point from its September 2012 level, to $13.1 \%$ (Table 1). Moreover, such drop in housing prices appears rather extreme, as they fell by only $13 \%$ following the 1997 crisis. The impact would be only slightly larger if the housing price decline were accompanied by a $20 \%$ drop in household income. According to a rating agency, the Tier 1 ratio of Korean banks would fall from $11.1 \%$ to $9.3 \%$ even if housing prices fell by $30 \%$ and the economy experienced a two-year recession (Moody's, 2013). As for interest rate risk, KIF projects that every 1 percentage-point 
increase in the interest rate would reduce bank profits, which amounted to a total of 9 trillion KRW in 2012, by 0.7 trillion KRW. The impact of interest rate hikes on profitability thus appears manageable. ${ }^{7}$

Table 1. The impact of economic shocks on the banking system

\begin{tabular}{|c|c|c|}
\hline Estimated by: & Economic shock & Impact \\
\hline Korea Institute of Finance & $20 \%$ drop in housing prices & $\begin{array}{c}1.1 \text { percentage-point drop in the } \\
\text { capital adequacy ratio }\end{array}$ \\
\hline Korea Institute of Finance & $20 \%$ drop in housing prices and household \\
income & $\begin{array}{c}1.2 \text { percentage-point drop in the } \\
\text { capital adequacy ratio }\end{array}$ \\
\hline Korea Institute of Finance & 1 percentage point rise in the interest rate & 0.7 trillion KRW fall in profits \\
\hline Moody's & $30 \%$ drop of housing prices and a two-year \\
recession & 1.8 percentage-point drop in Tier 1 \\
& & \begin{tabular}{c} 
capital \\
\hline
\end{tabular}
\end{tabular}

Source: Kim and Lim (2013) and Moody's (2013).

High household debt can impede economic growth

19. An increase in household debt can enhance the efficiency of inter-temporal resource allocation and boost private consumption, at least temporarily, by enabling consumers to use future income at present. However, once debt passes a certain point, the debt service burden tends to constrain consumption. A high level of household debt reduces macroeconomic stability and raises the risk of recession (OECD, 2012a). In particular, it makes households more vulnerable to changes in macroeconomic conditions, such as interest rates, income growth and asset prices, forcing them to modify their consumption. The risk of a recession therefore increases when debt rises; if the household debt ratio rises above trend by 10 percentage points of GDP, the probability of falling into recession the following year increases from $10 \%$ to $40 \%$ (OECD, 2012a). In the case of Korea, the negative impact of the interest payment burden has exceeded the liquidity effect of debt, which allows borrowers to increase expenditure, since 2006 (Na et al., 2013). Consequently, household debt is one of the factors hindering the growth of private consumption, which has lagged behind output growth since 2006 (Figure 7).

7. Given the current policy rate of $2^{1 / 2}$ per cent, an interest rate hike of more than 3 percentage points appears unlikely. The Bank of Korea's policy interest rate has not exceeded 51/4 per cent in this century. 
Figure 7. Private consumption growth has lagged behind GDP growth

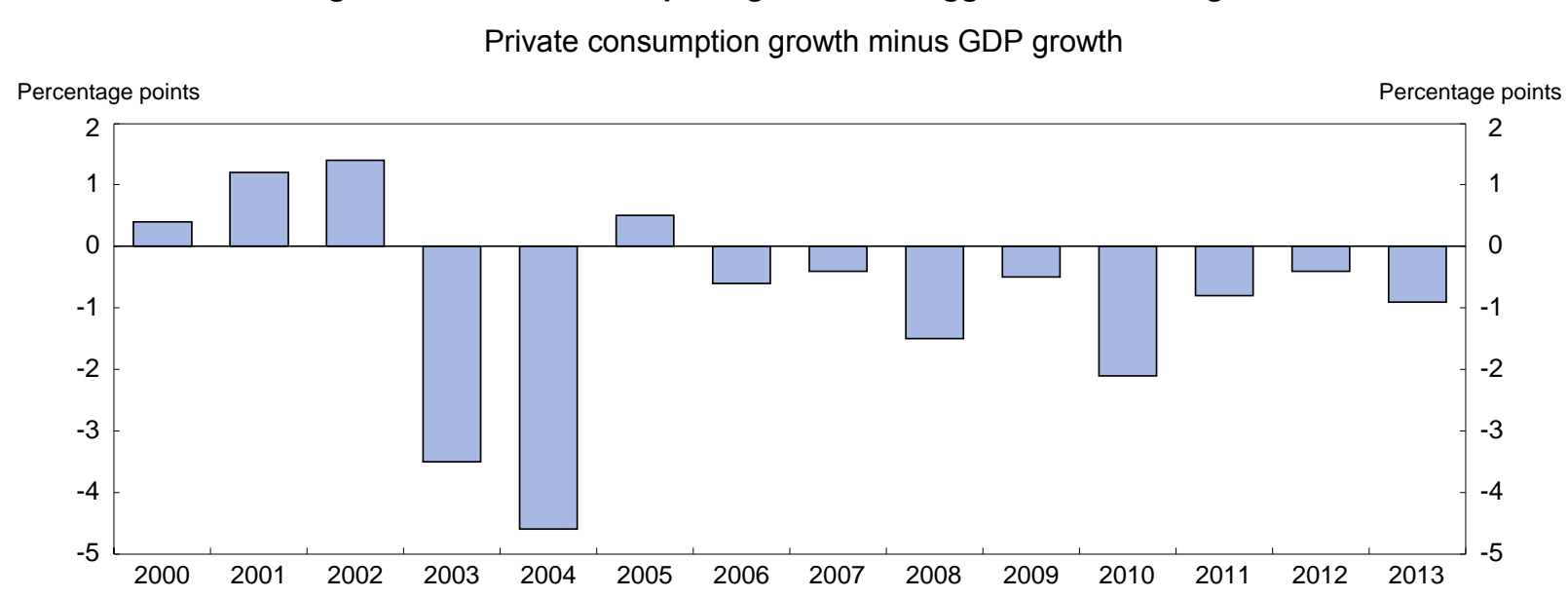

Source: OECD Economic Outlook Database.

\section{High household debt undermines social cohesion}

20. Household debt poses two challenges to social cohesion in Korea; $i$ ) how to provide sufficient credit to households with low income and credit ratings at an affordable price; and ii) how to restore the credit of people who are already delinquent and thus excluded from the regular financial market. The challenge of social cohesion has become more difficult, given the significant rise in income inequality since the 1997 crisis, while the relative poverty rate is now the eighth highest in the OECD area (OECD, 2013). This reflects the low level of social spending, which limits its impact on poverty and inequality. Given the undeveloped social safety net, low-income households are forced to seek finance by themselves for basic living expenses. As reported in the Bank of Korea survey of indebted households, $25 \%$ borrow money to pay for living costs (excluding housing). In particular, low-income households that suffer spells of unemployment, high health care costs or other financial losses have to rely on loans for basic necessities in the absence of an adequate social safety net. Given the subsequent burden of repaying the loan, the risk of delinquency and need for additional loans is high.

21. The challenge of providing sufficient funds to households with low income and credit ratings at an affordable price has been especially severe since the 2008 global financial crisis. While the financial needs of such households were increasing in the context of weak economic growth, their access to credit was hindered by the rising reluctance of financial institutions to lend to them. Indeed, between the third quarter of 2008 and the second quarter of 2009, the loan acceptance ratio - the number of loans agreed to by financial institutions divided by the number of credit checks - decreased from $70 \%$ to $28 \%$ for people with a low credit rating (Lee, 2010). ${ }^{8}$ Meanwhile, the ratio for persons with good ratings fell by less than 20 points. Consequently, the share of loans by financial institutions to individuals with low credit ratings fell from $29 \%$ in 2006 to $24 \%$ in 2009 and further to $18 \%$ in 2011-12 (Figure 8).

8. Korean credit rating agencies classify people into ten grades, with 10 as the lowest. In Lee's study, a grade between 7 and 10 was classified as low. According to the Korea Credit Bureau, a credit-rating agency specialised in personal credit and whose shareholders are 18 major financial institutions, 41 million people had credit ratings at the end of June 2013. Of them, 6 million (14\%) had grades of 7 to 10 . The number with credit ratings exceeds the 38.85 million Koreans aged 19 and over in 2011, reflecting the inclusion of some youth and some people who have passed away, given lags in updating the database. 
Figure 8. The share of loans to individuals with low credit ratings is falling

As a percentage of the outstanding loans of financial institutions

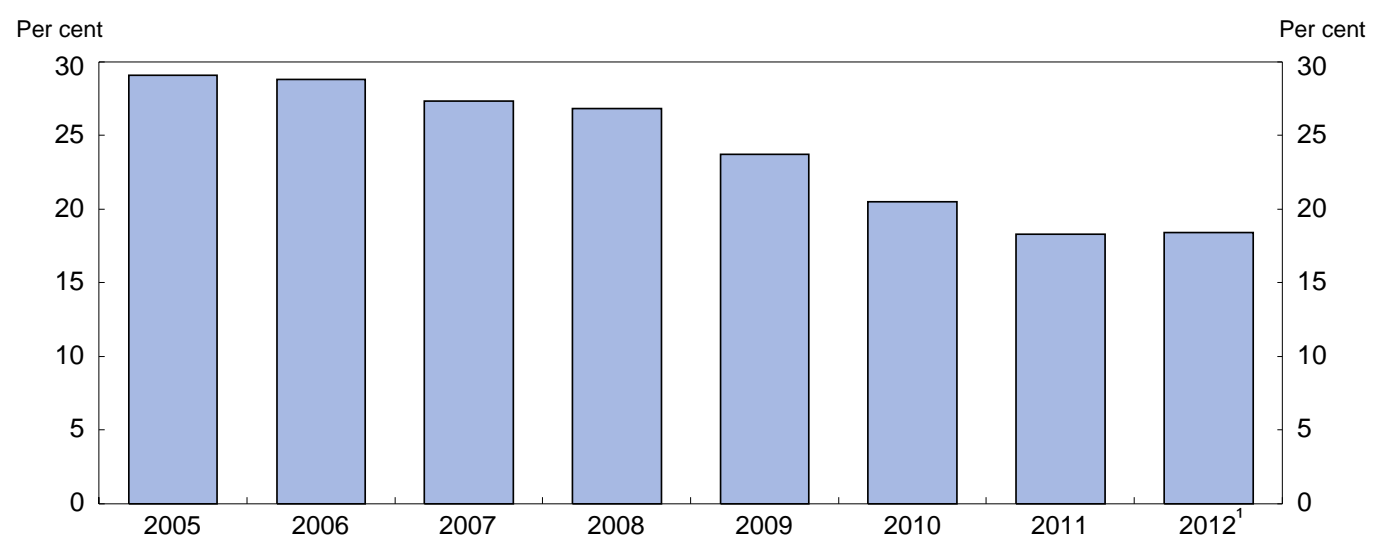

1. October 2012.

Source: Nam (2013)

22. Banks tend to lend to higher-income households. Indeed, they accounted for $46.3 \%$ of nonsecured lending (i.e. excluding mortgages) to borrowers with medium and high credit ratings but only $18.1 \%$ for those with poor ratings in 2012 (Table 2). Consequently, borrowers with poor credit ratings depended more on non-bank financial institutions (61.6\%) and consumer finance companies (20.2\%). Moreover, the share of banks and non-bank financial institutions in lending to households with poor credit ratings has fallen since 2010, while the share of consumer finance companies has risen. Of those who borrowed from consumer finance companies, including unregistered institutions, $44 \%$ needed loans to pay for living costs (FSS, 2013d). ${ }^{9}$

Table 2. The share of household lending by type of financial institution varies based on credit ratings ${ }^{1}$

In per cent

\begin{tabular}{lcccc}
\hline & \multicolumn{2}{c}{$\begin{array}{c}\text { Medium and strong } \\
\text { credit-rating borrowers }\end{array}$} & \multicolumn{2}{c}{$\begin{array}{c}\text { Poor credit-rating } \\
\text { borrowers }^{3}\end{array}$} \\
\cline { 2 - 5 } Lender & 2010 & 2012 & 2010 & 2012 \\
\hline Banks & 50.0 & 46.3 & 20.0 & 18.1 \\
Non-bank financial institutions & 49.0 & 52.0 & 65.4 & 61.6 \\
Consumer finance companies & 1.0 & 1.7 & 14.6 & 20.2 \\
\hline
\end{tabular}

1. Covers non-collateralised lending as a share of total non-collateralised lending.

2. Borrowers ranked 1 to 6 on the ten-point scale used by Korean credit-rating agencies.

3. Borrowers ranked 7 to 10 on the ten-point scale used by Korean credit-rating agencies.

Source: Bank of Korea (2013a).

23. In addition to the accessibility to finance, the wide variation in the interest rate charged on loans to households has a major impact on social cohesion. The rate ranges from an average of $6.9 \%$ in the case of banks to $38.1 \%$ for consumer finance companies (Bank of Korea, 2013a). According to the financial supervisors, the interest rate charged by banks varies from $5 \%$ to $14 \%$, well below the $25 \%$ to $40 \%$ of mutual saving banks, which are major players in lending to households with low income (Table 3). A 2013

9. In Korea, all consumer finance companies must register with the local government. Those that do not are operating illegally. 
government survey found that unregistered consumer finance companies charge $53 \%$ on average for household loans. Moreover, around one-fifth of borrowers with loans from such companies pay an interest rate of more than $100 \%$ (FSS, 2013d). Such high rates impose heavy burdens on borrowers with low incomes and credit ratings, thereby increasing the probability that they will become delinquent.

Table 3. Interest rates on loans to households vary widely by type of lender

\begin{tabular}{lcr}
\hline Lender & Credit rating of main borrowers $^{1}$ & Interest rate $(\%)^{\circ}$ \\
\hline Banks & $1 \sim 3$ & $5 \sim 14$ \\
Mutual co-operation financial institutions & $2 \sim 6$ & $10 \sim 25$ \\
Financial institutions specialised in lending & $4 \sim 7$ & $20 \sim 35$ \\
Mutual saving banks & $5 \sim 9$ & $25 \sim 40$ \\
Money lenders (consumer finance companies) & $7 \sim 10$ & $35 \sim 44$ \\
\hline
\end{tabular}

1. Based on the ten-point scale used by Korean credit-rating agencies. Source: Financial Services Commission (2011).

24. The question of how to assist households currently excluded from the regular financial market due to their failure to service their debts is another challenge to social cohesion. Information on delinquent borrowers is reported by the financial institution concerned to the Korea Federation of Banks and shared among financial institutions, making it nearly impossible for them to borrow from regular financial institutions. Therefore, they often turn to the black market which is not regulated by the authorities and where borrowers must pay extremely high interest rates, as noted above. At such high interest rates, it is nearly impossible to escape their debt and many lives are ruined by predatory lenders. The number of delinquent borrowers peaked at 3.7 million in 2003 with the bust of the credit card boom (Figure 9). By 2010, many of those borrowers had resolved their debts, reducing the number to 1.5 million in 2010. It has fallen further to 1.1 million by the end of 2013 , thanks in part to diverse programmes introduced by the government (see below). However, the number remains significant, at $5.4 \%$ of households.

Figure 9. The number of borrowers listed as delinquent has declined In million

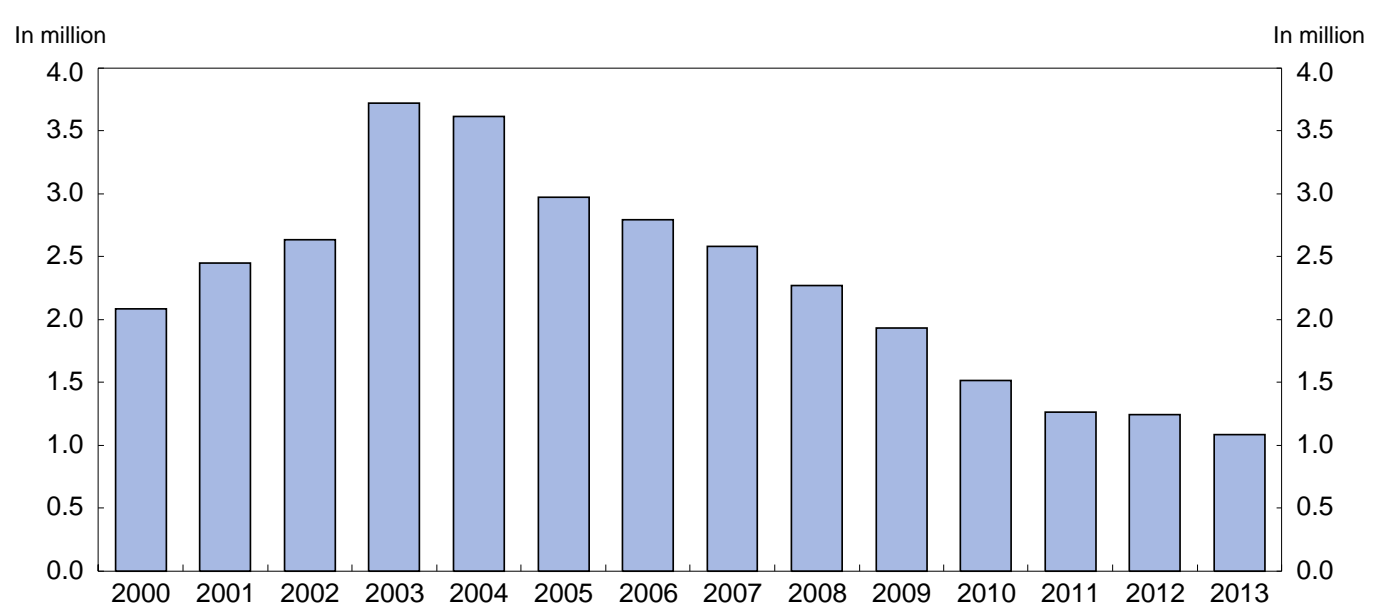

Source: Financial Services Commission.

\section{Policy responses to the household debt problem}

25. The government's bi-annual Economic Policy Directions published in 2009 and 2010 expressed concern about the level of household debt and housing loans, but did not propose explicit policy measures 
to address these issues. In June 2011, though, the financial authorities announced the "Comprehensive measures to induce the soft-landing of household debt" (Financial Services Commission and the Financial Supervisory Service, 2011). It stated that although the level of household debt in Korea was slightly higher than other advanced economies, it appeared to be manageable given such factors as the soundness of debt and the capacity of financial institutions to absorb potential losses. Nevertheless, the authorities argued that if potential risks, such as the structural weakness of mortgage loans, were not resolved, household debt could threaten economic and financial market stability. It was necessary, therefore, to take pre-emptive measures aimed at gradually reducing the household debt ratio to the OECD average. Achieving such a soft landing requires slowing the growth of household debt to a moderate rate, while avoiding measures that would induce a significant decline. The government clearly announced its intentions so as to not provoke a negative response in financial markets. Government policies are aimed at addressing the multiple dimensions of household debt, based on a two-track approach:

i. Expanding support for people with low credit ratings, as this group has been the most vulnerable to the weak economic conditions following the 2008 crisis.

ii. Enhancing the soundness of financial markets by containing the risk caused by the high level of household debt. This has been the priority since 2011 .

\section{Strengthening support for people with low income and credit ratings}

26. Due to the high risk of default and the lack of sufficient collateral, financial institutions limit their lending to people with low credit ratings and charge high interest rates on such loans (Table 3). However, households that borrow at a high interest rate have a higher probability of default, creating a vicious circle that further reduces lending to people with low income and credit ratings. This phenomenon is related to moral hazard and adverse selection. If a high interest rate is charged, only inferior borrowers whose probability of default is higher will agree to the loan, which further increases their risk of default. The goal of public support for households with low income and credit ratings is to help break this vicious circle. Such intervention was particularly necessary in the wake of the global crisis.

\section{Increasing preferential loans}

27. The government strengthened financial support to the poor by creating diverse channels for preferential loans.

- Miso Finance, established in 2008, is funded by dormant savings held in banks and contributions by financial institutions and large companies. It provides loans of up to 50 million KRW (about $\$ 48$ thousand) at an interest rate between $2 \%$ and $4.5 \%$ to people with a credit rating of seven or worse (Table 4). Miso Finance had established 165 branch offices throughout Korea by 2013.

- The Sunshine Loan programme was established in 2010 to provide preferential loans through financial institutions. Local credit guarantee funds, supported by central and local governments, provide credit guarantees for the loans of mutual saving banks and mutual credit institutions to households whose annual income was less than 20 million KRW (about \$19 thousand, close to the average per capita income of $\$ 22.6$ thousand in 2012) or whose credit rating was six or worse. Thanks to 283.1 billion KRW in government-funded credit guarantees, the interest rate was cut to between $11 \%$ and $14 \%$, far below the interest rates of more than $30 \%$ charged on loans to people with low income and credit ratings (FSC, 2010).

- Banks themselves also created a preferential loan programme, New Hope Seed Loans, in 2010 to support the government's priority of helping people with low income and credit ratings. 
Individuals with an annual income of less than 40 million KRW (about $\$ 38$ thousand, well above the average per capita income) and whose credit rating was five or worse are eligible. New Hope Seed Loans carry an interest rate of between $6 \%$ and $14 \%$.

Table 4. Preferential loans to people with low income and credit ratings

\begin{tabular}{|l|l|l|c|c|}
\hline \multicolumn{1}{|c|}{ Programme } & \multicolumn{1}{|c|}{ Channel } & \multicolumn{1}{|c|}{ Financing } & Eligibility & Interest rate $^{\mathbf{1}}$ \\
\hline $\begin{array}{l}\text { Miso Finance } \\
(2008)\end{array}$ & $\begin{array}{l}\text { Branches of Miso } \\
\text { Finance }\end{array}$ & $\begin{array}{l}\text { Dormant savings accounts } \\
\text { Financial institutions and large companies }\end{array}$ & $7 \sim 10$ & $2 \sim 4.5 \%$ \\
\hline $\begin{array}{l}\text { Sunshine } \\
\text { Loans }\end{array}$ & $\begin{array}{l}\text { Mutual Saving Banks } \\
\text { Mutual Credit } \\
\text { Institutions }\end{array}$ & $\begin{array}{l}\text { Financial institutions' own resources, with } \\
\text { publicly-funded credit guarantees }\end{array}$ & $6 \sim 10$ & $11 \sim 14 \%$ \\
\hline $\begin{array}{l}\text { New Hope } \\
\text { Seed Loans } \\
(2010)\end{array}$ & Banks & Banks' own resources & $5 \sim 10$ & $6 \sim 14 \%$ \\
\hline $\begin{array}{l}\text { Switch-Over } \\
\text { Dream Loan } \\
(2008)^{2}\end{array}$ & Banks & $\begin{array}{l}\text { Financial institutions' own resources, with } \\
\text { credit guarantees from the National } \\
\text { Happiness Fund }\end{array}$ & $6-10$ & Around 10\% \\
\hline
\end{tabular}

1. Based on the Korean credit rating system where 1 is the best and 10 is the worst.

2. This programme restructures existing loans with interest rates above $20 \%$.

Source: FSC (2011) and FSC (2012),

28. Along with preferential loan programmes, the government has tried to reduce the financial burden of the poor by reducing interest rates on loans to them. In particular, the interest rate ceiling on loans to individuals and small enterprises was lowered from $49 \%$ to $44 \%$ in 2010 , to $39 \%$ in 2011 and further to $34.9 \%$ in 2014. However, it is questionable whether such a regulation improves the situation for borrowers. Restricting the interest rate charged by financial institutions can instead increase reliance on unregistered consumer finance companies, which generally charge much higher interest rates that often exceed $100 \%$.

\section{Loan restructuring programmes}

29. In 2008, the government introduced the "Switch-Over Dream Loan", which allows certain borrowers to get a new loan using government credit guarantees provided through the Credit Recovery Fund..$^{10}$ The new loan has a lower interest rate, while the maturity can be extended. The programme accepts persons whose total debt is less than 30 million KRW (about \$29 thousand) and meet other conditions, such as a credit rating of six or worse and no history of loan delinquency.

\section{Promoting debt restructuring of delinquent loans}

30. Preferential loans and loan restructuring programmes are meant to prevent borrowers from falling into default. However, the government has also promoted the credit rehabilitation of delinquent borrowers, who numbered 2.3 million at the end of 2008 (Figure 9). One priority was to strengthen the out-of-court system for the credit recovery of delinquent borrowers as an alternative to the court-based system (Table 5). Under court procedures, delinquent borrowers can be absolved of their debt through the Individual Rehabilitation Programme, which requires debtors to pay the restructured debt for five years. This approach is usually applied to wage earners or business operators. The alternative is for the delinquent borrowers to file for bankruptcy and let the court settle the debt. Court-based solutions have handled an

10. The Credit Recovery Fund is financed by dormant savings accounts in financial institutions and by KAMCO, a public financial institution. 
average of 150 thousand debtors a year since 2008, although their share of restructuring delinquent loans has fallen from almost two-thirds to less than one-third (Table 6).

Table 5. The development of credit recovery support programmes for delinquent borrowers

\begin{tabular}{|l|l|l|}
\hline & \multicolumn{1}{|c|}{ Out-of-court system } & Court-based system \\
\hline Before the 2008 crisis & $\begin{array}{l}\text { Credit Counselling \& Recovery Service } \\
\text { - Individual workouts }\end{array}$ & Individual Rehabilitation Programme \\
\hline After the 2008 crisis & $\begin{array}{l}\text { Credit Counselling \& Recovery Service } \\
\text { - Individual workouts } \\
\text { - Pre-workouts (2009) } \\
\text { Credit Recovery Fund (2008) } \\
\text { - National Happiness Fund (2013) }\end{array}$ & Bankruptcy declared by the Court \\
\hline
\end{tabular}

Source: OECD.

31. Delinquent borrowers also have the option of turning to out-of-court measures to resolve their debt. Before the 2008 global crisis, the Credit Counselling and Recovery Service (CCRS), a non-profit corporation founded in 2002 when the number of delinquent borrowers increased rapidly due to credit card loans, played a major role in out-of-court credit recovery. The CCRS organised individual workouts based on agreements with financial institutions to extend maturity and lower the interest rate in order to reduce the burden on debtors (Table 5). As the financial difficulties of debtors intensified after the global financial crisis, the government created the pre-workout programme, which extended individual workouts to those who had failed to service their debt for between 30 and 90 days. The goal is to prevent borrowers who briefly become delinquent from falling into long-term delinquency.

Table 6. Programmes for credit recovery In thousand persons

\begin{tabular}{lrrrrrr}
\hline Programme & $\mathbf{2 0 0 8}$ & $\mathbf{2 0 0 9}$ & $\mathbf{2 0 1 0}$ & $\mathbf{2 0 1 1}$ & $\mathbf{2 0 1 2}$ & $\mathbf{2 0 1 3}^{\mathbf{2}}$ \\
\cline { 2 - 6 } Individual workouts (out-of-court) $^{1}$ & 88 & 155 & 168 & 163 & 136 & 319 \\
Individual recovery (in-court) $^{\text {Individual default (in-court) }}$ & 48 & 55 & 47 & 65 & 90 & 96 \\
Total & 119 & 111 & 85 & 70 & 62 & 52 \\
\hline
\end{tabular}

1. Includes pre-workouts, introduced in April 2009 and the National Happiness Fund, launched in 2013.

2. November 2013.

Source: Financial Services Commission.

32. In addition, the Credit Recovery Fund, the public institution which runs the loan-exchange programme discussed above, also helps to resolve delinquent loans. The Fund buys delinquent assets from financial institutions at a discounted price and then modifies the conditions of each loan so as to make it possible for the borrowers to service their debt. The reduction of principal is not allowed in principle in order to prevent debtors' moral hazard (FSC, 2012). However, the new administration inaugurated in 2013 further developed the Credit Recovery Fund by creating the "National Happiness Fund", which can reduce principal by up to $70 \%$ (Box 3 ).

\section{Containing the growth of household debt and removing potential risk factors within household debt}

33. To achieve a soft landing in the household debt ratio, the authorities have strengthened prudential measures on financial institutions. For example, a higher risk weight was applied to loans given to multiple 
borrowers, defined as those with three or more loans from financial institutions, in calculating banks' capital adequacy ratio. The objective is to slow banks' lending to multiple borrowers given the higher risk of default of such loans. Leverage regulation was also strengthened. Banks were requested to lower their loan-to-deposit ratio below $100 \%$ by the end of June 2012. In addition, regulations on non-bank financial institutions were tightened. For financial institutions specialised in lending, such as credit card companies, leverage regulation was introduced and their special treatment regarding corporate bond issuance was abolished. Credit card companies had been allowed to issue corporate bonds up to ten times their capital, far above the general limit of four, to expand their lending. The amount of reserves that the companies must hold against delinquent assets was also increased in order to contain the growth of household debt and enhance the capability of financial institutions to absorb any losses related to it.

34. While government policies have been successful in slowing the growth of bank lending to households, the impact was offset by faster growth in lending by non-bank financial institutions. Since 2007, the growth of household debt by non-bank financial institutions has outpaced that of banks each year (Figure 10). Indeed, bank loans to households rose by $29 \%$ over the period 2007-12, lagging behind the overall increase of $44 \%$, reflecting the "balloon effect": the regulations on banks simply shifted borrowing to non-bank financial institutions (Kim et al., 2013). Consequently, banks' share of household debt fell from $57.7 \%$ in 2007 to $51.6 \%$ in 2012 . 


\section{Box 3. The National Happiness Fund}

The National Happiness Fund (NHF) was launched in March 2013 to promote the credit recovery of delinquent borrowers. Individuals who had borrowed less than 100 million KRW ( $\$ 96$ thousand) and were overdue by six months or longer as of the end of February 2013 are eligible for debt restructuring (Table 7). Financial institutions and nonbank lenders that signed agreements with the NHF for credit recovery assistance must sell overdue loans to the NHF if their borrowers apply for debt restructuring. As of October 2013, 4214 institutions had signed such agreements.

Table 7. Debt restructuring process under the National Happiness Fund

\begin{tabular}{|c|c|c|}
\hline & $\begin{array}{l}\text { Debt restructuring by borrowers' prior } \\
\text { application }\end{array}$ & $\begin{array}{c}\text { Debt restructuring by borrowers' later } \\
\text { consent }\end{array}$ \\
\hline Eligible applicants & $\begin{array}{l}\text { Individuals with debt of less than } 100 \text { million } \\
\text { KRW, overdue for six months or longer as of } \\
\text { end-February } 2013 \text {, who applied between } \\
1 \text { May and } 31 \text { October } 2013 .\end{array}$ & $\begin{array}{l}\text { The NHF purchases loans from enlisted } \\
\text { institutions and then conducts restructuring } \\
\text { with the consent of borrowers with debt of } \\
\text { less than } 100 \text { million KRW, overdue for six } \\
\text { months or longer as of end-February } 2013 .^{1}\end{array}$ \\
\hline Benefits & $\begin{array}{l}\text { - Up to } 70 \% \text { of debt can be written off } \\
\text { depending on the applicant's age, period of } \\
\text { overdue payment, income level } \\
\text { - Repayment schedule can be extended by } \\
\text { up to } 10 \text { years }\end{array}$ & $\begin{array}{l}\text { Benefits equivalent to those of debt } \\
\text { restructuring by prior application. However, } \\
\text { the rate of debt write-off is less than debt } \\
\text { restructuring by prior application. }\end{array}$ \\
\hline How to apply & $\begin{array}{l}\text { Application from } 1 \text { May to } 31 \text { October } 2013 \text { at } \\
\text { branches of KAMCO, the Credit Recovery } \\
\text { Foundation and micro-credit centres. }\end{array}$ & $\begin{array}{l}\text { The NHF will individually contact borrowers } \\
\text { eligible for the programme after July } 2013 \text { to } \\
\text { confirm their consent to debt restructuring. }\end{array}$ \\
\hline
\end{tabular}

1. Those who borrowed from unregistered money lenders, have secured loans (such as mortgages) or who are already enrolled in other credit recovery programmes are not eligible.

Source: Korea Asset Management Corporation.

Restructuring is accomplished on two tracks: i) debtors who applied between May and October 2013; and ii) the NHF can first purchase the delinquent loans from the enlisted financial institutions and then conduct debt restructuring by obtaining consent afterwards. Between $50 \%$ and $70 \%$ of the debt, including both principal and interest, can be written off depending on a number of factors, such as the borrower's age, income and assets and the length of time that the loan has been delinquent. In addition, the maturity of debt can be extended by up to ten years.

During the six-month application period, 214 thousand delinquent borrowers applied for credit restructuring through the NHF (Table 8). Of the applicants, $62 \%$ are in the 40 -to-60 age group (Panel A) and more than half have an annual income of less than 10 million KRW (about \$9 600) (Panel B). The average debt amounts to only 11.5 million $\mathrm{KRW}$ and $63 \%$ have less than 10 million KRW in debt (Panel C). The average delinquency period is 72 months, with more than half delinquent for more than four years (Panel D). If those accepted into the NHF are found to have undeclared assets or do not faithfully fulfil their debt restructuring obligation, they are expelled from the programme.

In addition to the restructuring of delinquent debt, the NHF also eases the burden of student loans, by writing them off or rescheduling them, depending on borrowers' ability to pay. The NHF also reduces the interest rate on loans carrying rates of $20 \%$ or more to $10 \%$ for borrowers who had consistently serviced their debt for six months or longer as of February 2013 and earn less than 40 million KRW a year. Up to 40 million KRW of high-interest loans can be converted to low-interest ones.

As for the financing of the NHF, 1.5 trillion KRW $(0.1 \%$ of GDP) is expected to be necessary to cover the majority of the delinquent borrowers. Of this amount, 800 billion KRW is to be financed by a fund controlled by a public financial institution (the Korea Asset Management Corporation [KAMCO]), loans and bond issuance. The remaining 700 billion $\mathrm{KRW}$ is to be financed by the NHF's revenues from the restructured loans. KAMCO, which played the major role in acquiring non-performing loans from financial institutions following the 1997 crisis, is helping individual debtors through credit recovery using the NHF, financial support (credit guarantees and mini-loans) and help for job seekers. 


\begin{tabular}{|c|c|c|c|c|c|}
\hline \multicolumn{6}{|c|}{ In per cent as of end-October 2013} \\
\hline $\begin{array}{l}20 \mathrm{~s} \\
7.0 \% \\
\end{array}$ & $\begin{array}{c}30 \mathrm{~s} \\
21.0 \% \\
\end{array}$ & $\begin{array}{c}40 \mathrm{~s} \\
33.4 \% \\
\end{array}$ & $\begin{array}{c}50 \mathrm{~s} \\
28.8 \% \\
\end{array}$ & $\begin{array}{c}60+ \\
9.8 \% \\
\end{array}$ & $\begin{array}{l}\text { Total } \\
100 \% \\
\end{array}$ \\
\hline \multicolumn{6}{|c|}{ B. Annual income (in million KRW) ${ }^{1}$} \\
\hline $\begin{array}{c}\text { Less than } 10 \\
55.7 \%\end{array}$ & $\begin{array}{r}10-20 \\
27.4 \% \\
\end{array}$ & $\begin{array}{l}20-30 \\
10.7 \% \\
\end{array}$ & $\begin{array}{l}30-50 \\
5.2 \% \\
\end{array}$ & $\begin{array}{c}\text { Over } 50 \\
1.0 \% \\
\end{array}$ & $\begin{array}{l}\text { Total } \\
100 \% \\
\end{array}$ \\
\hline \multicolumn{6}{|c|}{ C. Debt amount (in million KRW) ${ }^{2}$} \\
\hline $\begin{array}{c}\text { Less than } 5 \\
40.1 \%\end{array}$ & $\begin{array}{c}5-10 \\
22.8 \%\end{array}$ & $\begin{array}{r}10-20 \\
21.0 \%\end{array}$ & $\begin{array}{l}20-30 \\
8.5 \%\end{array}$ & $\begin{array}{c}\text { Over } 30 \\
7.7 \%\end{array}$ & $\begin{array}{l}\text { Total } \\
100 \%\end{array}$ \\
\hline \multicolumn{6}{|c|}{ D. Delinquency period (number of years) ${ }^{3}$} \\
\hline $\begin{array}{c}\text { Less than } 1 \\
2.7 \% \\
\end{array}$ & $\begin{array}{c}1-2 \\
21.3 \% \\
\end{array}$ & $\begin{array}{c}2-3 \\
14.2 \% \\
\end{array}$ & $\begin{array}{l}3-4 \\
8.2 \% \\
\end{array}$ & $\begin{array}{c}\text { More than } 4 \\
53.7 \% \\
\end{array}$ & $\begin{array}{l}\text { Total } \\
100 \% \\
\end{array}$ \\
\hline $\begin{array}{l}\text { 1. Average incon } \\
\text { 2. Average debt } \\
\text { 3. Average delin } \\
\text { Source: Financial S }\end{array}$ & $\begin{array}{l}\text { million KR } \\
\text { ion KRW. } \\
\text { riod is } 72 \text { r } \\
\text { mmission }\end{array}$ & & & & \\
\hline
\end{tabular}

Figure 10. Non-bank financial institutions account for most of the growth in household debt

The increase in the amount of loans ${ }^{1}$

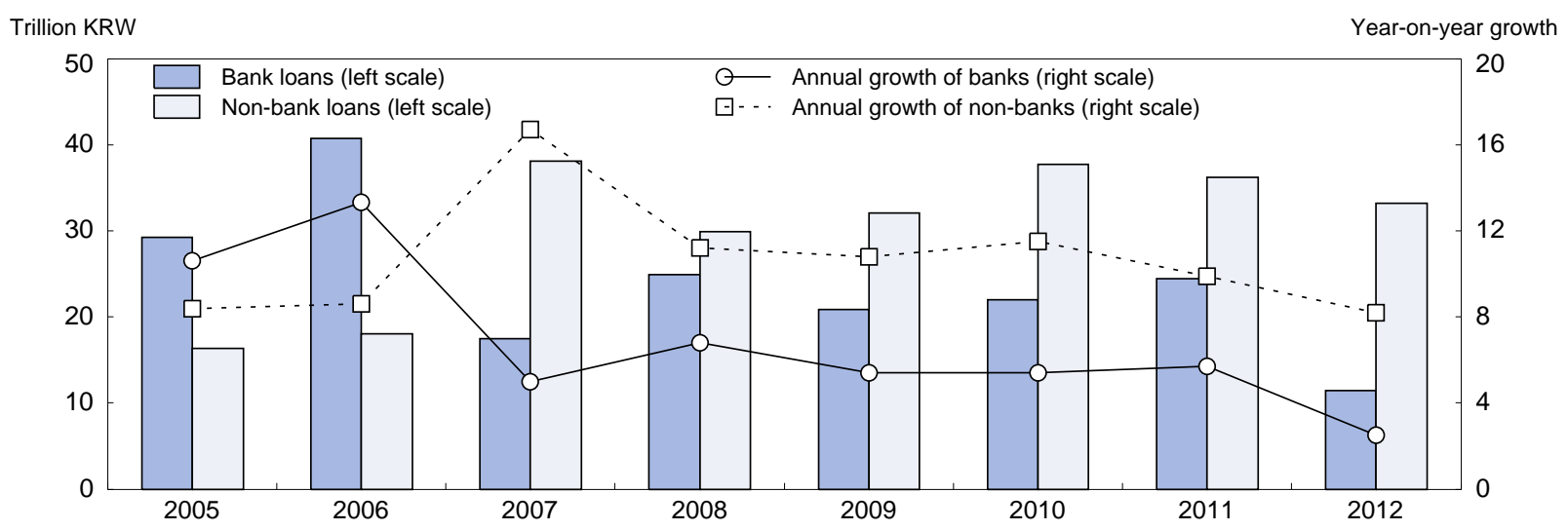

1. Includes mortgage lending and other secured loans.

Source: FSC et al. (2012) and FSC (2013).

35. In 2012, the authorities took additional measures to contain the rapid growth of household lending by extending the tighter regulations on leverage and loan-loss reserves to non-bank financial institutions (FSC et al., 2012). Mutual credit institutions were required to lower the deposit-to-loan ratio to below $80 \%$. Moreover, the risk weight for household debt in calculating their capital adequacy ratio was increased from $35 \%$ to $50 \%$ in the case of risky household debt, such as mortgage loans with bullet repayment and loans to multiple borrowers. 
36. In addition, comprehensive measures, including tax incentives and financial regulations, were introduced to address the structural weaknesses of household debt. The government introduced a preferential tax credit for mortgage loans with fixed interest rates and instalment repayment without a grace period. In 2010, the authorities also required banks to raise the share of mortgage loans with fixed interest rates and instalment repayments from $0.5 \%$ and $6.4 \%$, respectively, in 2010 to $30 \%$ by the end of 2016 (Table 9). The FSS monitors banks' progress in implementing the plans. In addition, the government strengthened its support for the issuance of mortgage-backed securities (MBS) by the Korea House Financing Corporation $(\mathrm{KH})$ in order to absorb the risk that banks incur in making mortgage loans with fixed rate and instalment repayments. The KH buys fixed-rate mortgage loans from financial institutions and issues MBS that usually have a longer maturity and fixed interest rate, on the basis of loans bought. This enables financial institutions to transfer the credit, interest rate and liquidity risk that are generated by fixed-rate mortgages to the $\mathrm{KH}$.

Table 9. The share of fixed rate and instalment repayment mortgage loans of banks

\begin{tabular}{lc|cc|cc|ccc}
\hline & \multirow{2}{*}{2010} & \multicolumn{2}{|c|}{2011} & \multicolumn{2}{c|}{2012} & \multicolumn{2}{c}{2013} \\
& & Target & Outcome & Target & Outcome & \multicolumn{2}{c}{ Target } & Outcome \\
\cline { 2 - 8 } Fixed-rate loans & 0.5 & 2.1 & 3.1 & 6.2 & 14.2 & 11.1 & 15.9 \\
Instalment repayment loans & \multirow{2}{*}{} & 6.4 & 7.3 & 7.7 & 10.4 & 13.9 & 14.2 & 18.7 \\
\hline
\end{tabular}

1. A loan that is repaid over a fixed time period with a set number of scheduled payments. Source: FSS (2014).

\section{Impact of recent policies and measures needed to address remaining challenges}

\section{Although household debt accumulation has slowed, its ratio to disposable income is still rising}

37. The policies discussed above helped to halve the growth of debt from $9.6 \%$ in 2010 to $4.8 \%$ in 2012 (Figure 11). However, the growth of household disposable income also slowed, falling to only $4.2 \%$ in 2012. Consequently, the upward trend in the ratio of household debt to disposable income has continued, albeit only slightly in 2012, making households even more sensitive and vulnerable to macroeconomic conditions, including interest rates, income and assset prices. In addition, the high level of household debt continues to constrain consumption growth. While households are able to service their debt, this is being achieved primarily by cuts in consumption rather than by income gains (Hwang and Jung, 2013).

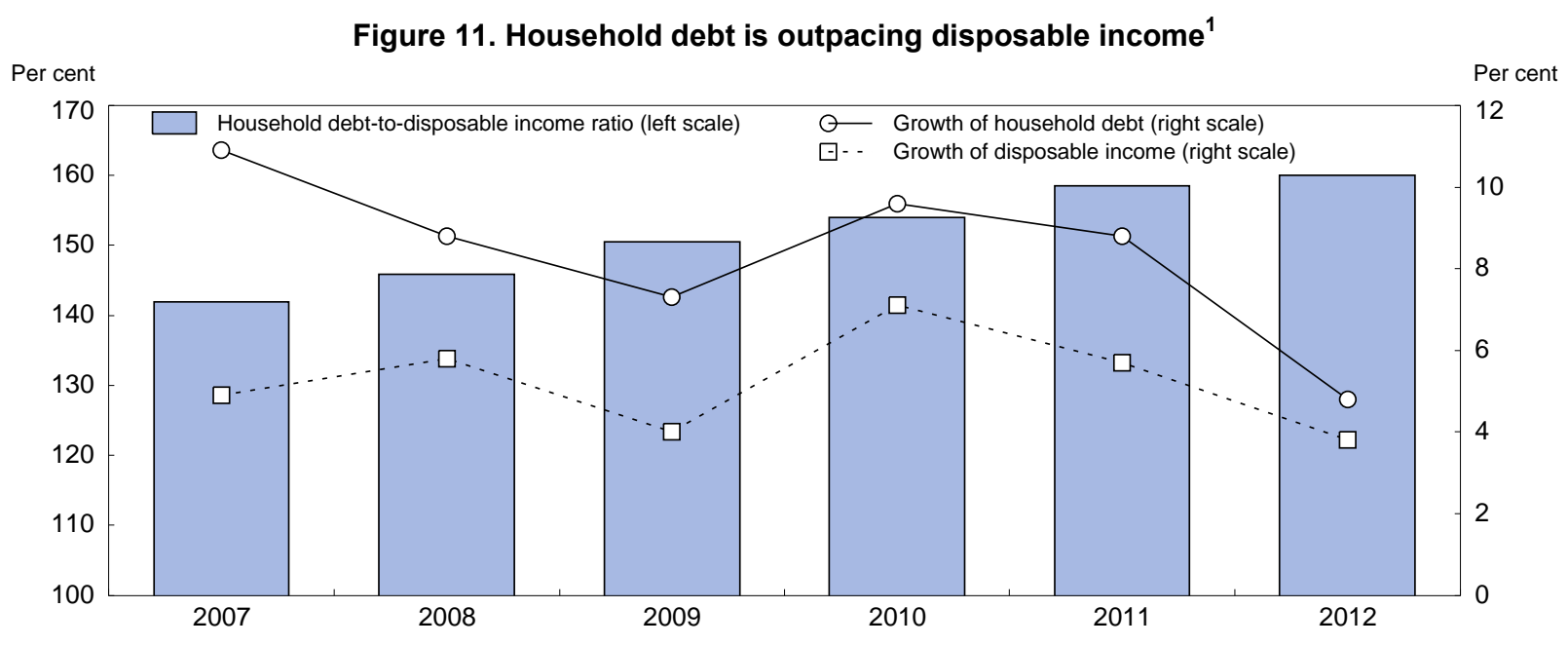

$1 . \quad$ Based on SNA2008 data.

Source: OECD Economic Outlook Database. 
38. Considering the already-high level of household debt compared with other OECD countries and its negative impact on private consumption and output, it is important to contain the growth of household debt. The government's objective, announced in 2011, to gradually reduce the household debt ratio to the OECD average is appropriate. This requires containing the growth of household debt to a moderate rate below the growth of household income. That suggests that measures to boost output growth through the government's initiative to foster a creative economy and through other reforms (2014 OECD Economic Survey of Korea) also have an important role to play in addressing the household debt problem.

39. At the same time, it is important to avoid a sharp fall in the household debt ratio, as occurred during the collapse of the credit card bubble in 2003, which sharply slowed output growth. In the short run, there is a risk of such a decline, given financial institutions' heightened awareness of the risk attached to household debt and the moderate growth of domestic demand. Moreover, the liquidity situation in Korea will be influenced by raising interest rates on Korean Treasury bonds, which tend to be linked to US Treasury yields. The government should clearly communicate its target of a soft landing of household debt and explain what further measures are necessary to achieve it, thereby avoiding any misunderstanding by market players and ensuring predictability about policy directions.

40. To slow the growth of household debt, past experience suggests that the financial supervisory authorities should closely monitor financial institutions' behavior, in addition to the standard indicators of capital adequacy and loan delinquency, which are lagging indicators of market conditions. During the credit card bubble, rapid increases in asset prices put downward pressure on the delinquency ratio, more than offsetting the rise in distressed loans. Consequently, lending risks tended to be under-evaluated, resulting in reckless lending behaviour by financial institutions that further boosted asset prices. Financial supervisory authorities thus need to consider both numerical and behavioural information to correctly evaluate market developments and their policy implications so as to respond in a timely manner.

41. Household debt cannot be effectively addressed only through financial supervision, as it is also related to monetary policy and general economic policy, including taxation and regulations in the housing market. As noted above, mortgage loans account for about half of household debt. This implies a need for close co-operation between the financial supervisory authorities and other institutions, notably the Ministry of Strategy and Finance and the Bank of Korea, to share information, enhance mutual understanding on the household debt issue and co-ordinate timely actions.

\section{Reducing structural weaknesses in household debt}

42. In addition to containing the aggregate level of household debt, the authorities should address the risks attached to it. As the most serious risks are related to the housing market, resolving the issues in this sector would be beneficial for the household debt issue and financial markets in general. Despite recent progress, the shares of fixed-rate and instalment repayment mortgages are still far lower than in other OECD countries. The financial authorities should continue monitoring the progress of banks toward the $30 \%$ target in 2016 (Table 9). Thus far, the banks have outperformed their commitments to increase the share of fixed-rate and instalment loans, reaching $15.9 \%$ in 2013 . The government programme, though, does not include any targets on increasing the maturity of loans, which would also help reduce risk.

43. To achieve the target for fixed-rate and instalment loans, the government needs to share the burden borne by banks when they raise the share of fixed-rate and instalment repayment loans by strengthening the role of $\mathrm{KH}$, which takes the risk from banks by issuing MBS. At the same time, to avoid having this market dominated by the public sector, competition between private and public institutions should be encouraged. The government should develop the infrastructure necessary for a private MBS 
market. This requires the introduction of covered bonds, ${ }^{11}$ which are issued on the basis of assets such as mortgage loans. Legislation to allow covered bonds took effect in April 2014. In sum, through MBS and covered bonds, financial institutions will be able to issue bonds at low interest rates with a long maturity.

44. Another concern related to the mortgage market is the LTV ratio. The average LTV ratio of nine large commercial banks, which was stable at around $47 \%$ between 2009 and 2011 , edged up to $49 \%$ in early 2013, reflecting the decline in housing prices (Figure 12). Meanwhile, the share of mortgage loans with a LTV ratio above $70 \%$ reached $3.5 \%$ (8.3 trillion KRW in terms of amount). This increases the risk to banks as the delinquency ratio of such loans was $2.3 \%$ at the end of 2012 , compared to only $0.5 \%$ for those with a LTV of $70 \%$ or below (Bank of Korea, 2013a).

Figure 12. The average loan-to-value ratio has trended up in recent years

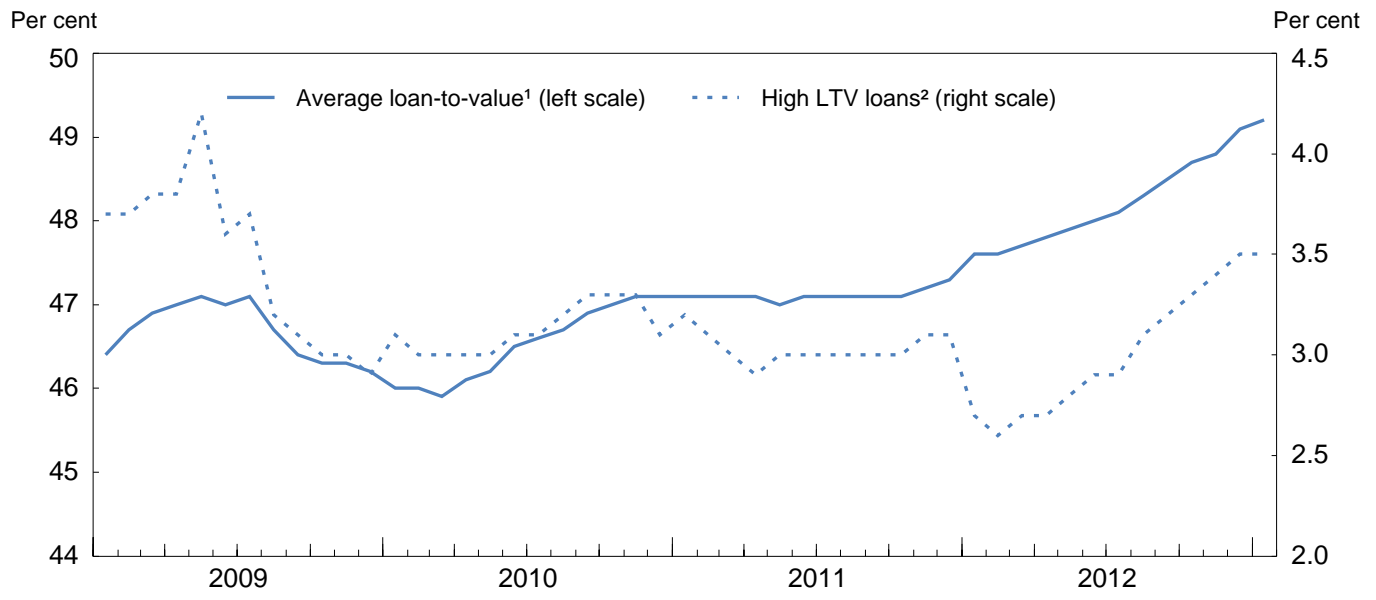

1. Average of nine large commercial banks.

2. The share of mortgages with a loan-to-value ratio of over $70 \%$ as a share of all mortgages.

Source: Bank of Korea (2013a).

45. During the past decade, the price of housing and the household debt ratio have been positively correlated (Figure 13). In the short run, it seems most important to prevent a self-fulfilling vicious circle of falling real housing prices by reversing expectations that the decline, which started in 2008, will continue. If housing prices were to fall sharply, the LTV ratio would rise above the level stipulated by the authorities and financial institutions would be less willing to roll over bullet loans. This would prompt a fire sale of houses, further lowering housing prices.

46. However, it is both difficult and dangerous to boost the housing market by encouraging people to purchase homes with more debt, given the already high level of household debt in Korea. A better approach would be to improve and streamline the legal and regulatory framework of the housing market to promote its healthy development while maintaining appropriate prudential measures in financial markets. Such reforms are increasingly urgent given signs of significant structural changes in the housing market. In particular, the traditional Korean chonsei system (Box 2) is beginning to weaken for several reasons. First, expectations that housing prices will increase continuously, which underpins this market, are weakening. Moreover, people are focusing more on the role of a house as a residence rather than an investment.

11. Covered bonds are different from MBS because the asset is not separated from financial institutions. The rights of holders of covered bonds are secured based both on the asset itself and the financial institution. The introduction of covered bonds required legislation because the underlying asset (housing loans) is considered to be separated from banks, as is the case for MBS, although it is still legally owned by banks. 
Second, interest rates, including on mortgage loans, have been low for a long time, making it much easier for prospective borrowers to get mortgages. However, the impact of a shrinking role for the chonsei system on household debt is uncertain. On the one hand, it may encourage the purchase of homes, thereby expanding household debt. On the other hand, more households may rent housing on a monthly basis, thereby eliminating the deposit required in the chonsei system and reducing household borrowing to accumulate the deposit and thereby lowering household debt.

Figure 13. Household debt and the housing price are linked

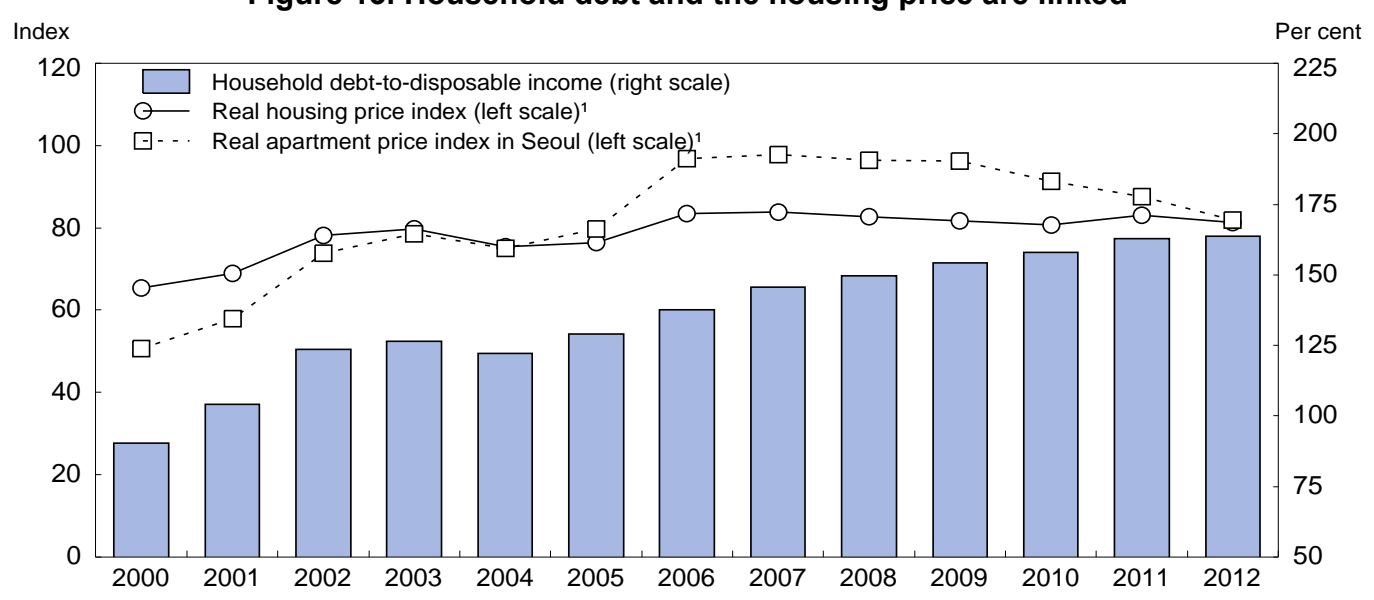

1. March 2013 equals 100

Source: Bank of Korea.

47. Reflecting the changes in the housing market, the government is revising laws and regulations established when house prices were rising during the mid-2000s. The main purpose of those regulations was to constrain demand for housing by increasing the cost of buying, selling and owning houses, especially for persons owning more than one home. In Korea, the property tax on home owners has been relatively low at $0.1 \%$ to $0.4 \%$. In 2004 , though, Korea introduced the comprehensive real estate tax, which is high at $0.5 \%$ to $2.0 \%$ and complex. This tax applies to owners of homes valued together at more than 600 million KRW (about $\$ 578$ thousand) or a single home valued at more than 900 million KRW. Korea is the only OECD country that imposes a comprehensive national property tax on housing. Nevertheless, property-holding taxes were relatively low at $0.8 \%$ of GDP in 2010 , compared to the OECD average of $1.1 \%$ (Table 10). Given that property taxation is a relatively efficient means for raising revenue, the rate should be increased. However, the comprehensive property tax should be merged with the local property tax, given the efficiency of such taxes for local governments.

Table 10. The tax mix in OECD countries

Tax revenue as a per cent of GDP

Direct taxes on households

Direct taxes on firms

Social security and payroll

Goods and services

Property

Holding taxes

Taxes on property transactions

Estate, inheritance and gift taxes

Other

Total

\begin{tabular}{cc|ccc|c}
\multicolumn{2}{c|}{2000} & \multicolumn{3}{c|}{$\mathbf{2 0 1 2}$} & Change $^{1}$ \\
\hline Korea & OECD & Korea & Rank & OECD & $\mathbf{2 0 0 0 - 1 2}$ \\
\hline 3.3 & 9.3 & 4.0 & 29 & 8.7 & 0.7 \\
3.2 & 3.4 & 4.0 & 5 & 3.0 & 0.8 \\
3.8 & 9.2 & 6.7 & 24 & 9.6 & 2.9 \\
8.7 & 11.3 & 8.4 & 28 & 11.1 & -0.3 \\
2.8 & 1.9 & 2.8 & 7 & 1.8 & 0.0 \\
0.6 & 0.9 & 0.8 & 16 & 1.1 & 0.2 \\
2.0 & 0.6 & 1.7 & 1 & 0.4 & -0.3 \\
0.2 & 0.1 & 0.3 & 4 & 0.1 & 0.1 \\
0.8 & 0.2 & 0.9 & 1 & 0.1 & 0.1 \\
$\mathbf{2 2 . 6}$ & $\mathbf{3 5 . 3}$ & $\mathbf{2 6 . 8}$ & $\mathbf{3 0}$ & $\mathbf{3 4 . 5}$ & $\mathbf{4 . 2}$ \\
\hline
\end{tabular}

1. In percentage points. 
48. Taxes on real estate transactions are more burdensome. For example, when a house is purchased in Korea, the buyer has to pay the acquisition tax, which ranged from $2 \%$ to $4 \%$ until 2014 , a high rate compared to other OECD countries. In addition, the seller must pay a capital gain tax, which has standard rates between $6 \%$ and $38 \%$, but with rates of up to $60 \%$ for those who own multiple homes. The high tax burden on housing has reduced demand and damped activity in the housing market. Indeed, the number of real estate transactions fell by one-third nationwide and by two-thirds in Seoul over 2006-13 (MLIT, 2013). The small number of transactions frustrates the market's ability to efficiently match supply and demand. In sum, high transfer taxes hinder the rebalancing of the housing market and further lower expectations for housing prices.

49. The cut in the capital gains tax on multiple home owners to the standard rates from $6 \%$ to $38 \%$ in January 2014 and the reduction in the acquisition tax to $1 \%$ to $3 \%$, as recommended by the OECD, is a positive development. These changes have already significantly boosted real estate transactions in Seoul in early 2014. Finally, financial institutions should be allowed more flexibility in applying the LTV ratio, which is relatively strict by international standards.

50. Another risk factor for banks is the large debt of "multiple loan borrowers", defined as persons with loans from three or more financial institutions. The default rate of multiple loan borrowers increased from $3.3 \%$ at the end of 2010 to $4.6 \%$ at the end of 2012, whereas that of other borrowers has been steady at around $2.6 \%$. Moreover, default by multiple loan borrowers can create a chain reaction. If a borrower defaults on one loan, the information is registered at the Korea Federation of Banks and shared among financial institutions. Those with loans to the delinquent borrower often demand that the borrower immediately pay back their loan when their concern about household debt is high. As a result, the default on one loan can lead to additional defaults, thereby creating risks for the financial system. The possibility of such chain reactions was magnified by the increase in the amount of multiple loans from around 262 trillion KRW in mid-2010 to 308 trillion KRW at the end of 2011 (Figure 14), accounting for one-third of total household loans (Bank of Korea, 2013a). Strengthened risk management by bank and non-bank financial institutions, though, helped stabilise the number of multiple loan borrowers and the size of loans in 2012. However, this forced the debtors to borrow greater amounts from consumer finance companies, which charge a much higher interest rate, resulting in a deterioration in the quality of the debt of multiple loan borrowers (Bank of Korea, 2013a).

Figure 14. The debt of borrowers with multiple loans ${ }^{1}$ is increasing

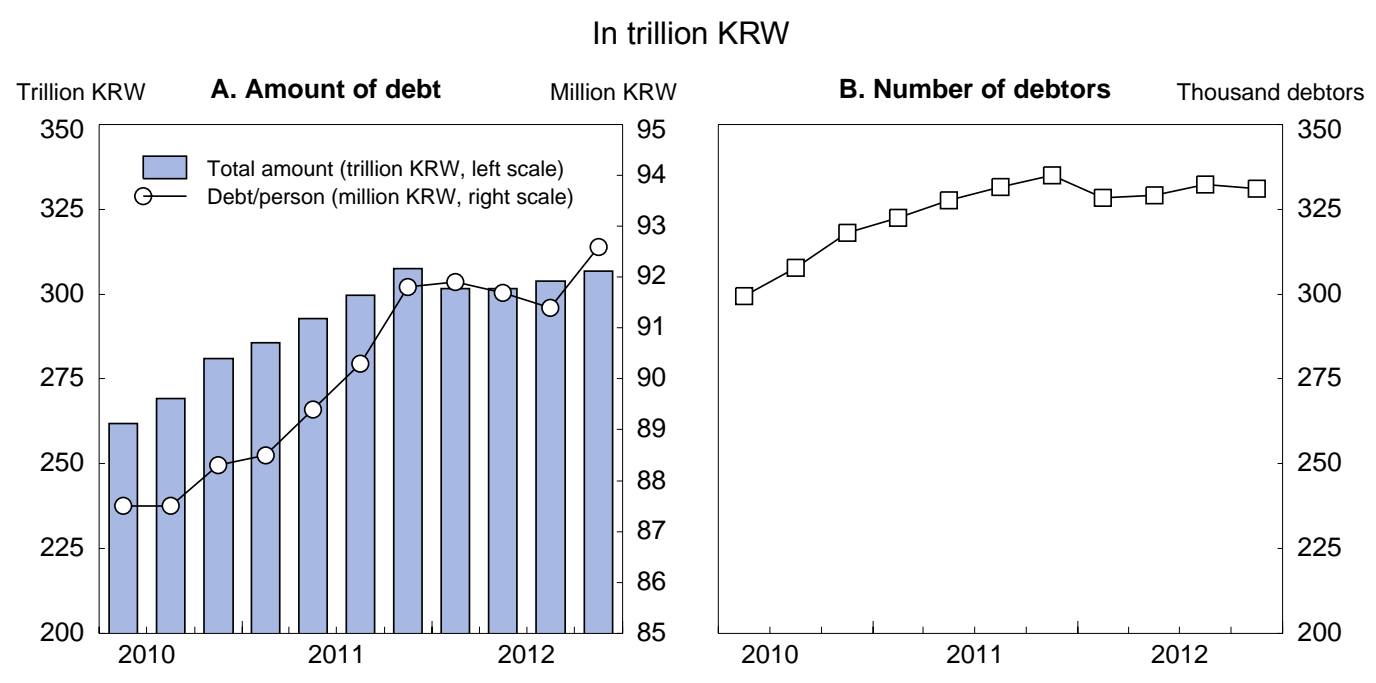


1. Defined as persons with loans from three or more financial institutions.

Source: Bank of Korea (2013a).

\section{Limiting the risks posed by household debt for financial institutions}

51. Reducing structural weaknesses in household debt will reduce the risks to banks. As noted above, the share of distressed loans has been maintained at a low level and the capacity of banks to absorb potential losses seems sufficient (Figure 5). However, the substandard and below loan ratio of household debt has been edging up, from $0.5 \%$ in 2009 to $0.7 \%$ in 2012. As for mutual banks, the share of distressed loans (one month overdue) in lending to households was $13.0 \%$.

52. The quality of corporate loans has been deteriorating, reducing the capacity of banks to absorb potential losses from household debt. In 2013, the after-tax profit of banks fell to 4.0 trillion KRW, less than half of the 8.7 trillion KRW in 2012 (Figure 15), due to a decrease in the net interest margin and significant losses in the shipbuilding and marine transport industries (FSS, 2013a).

Figure 15. The ability of banks to absorb potential loss from household debt

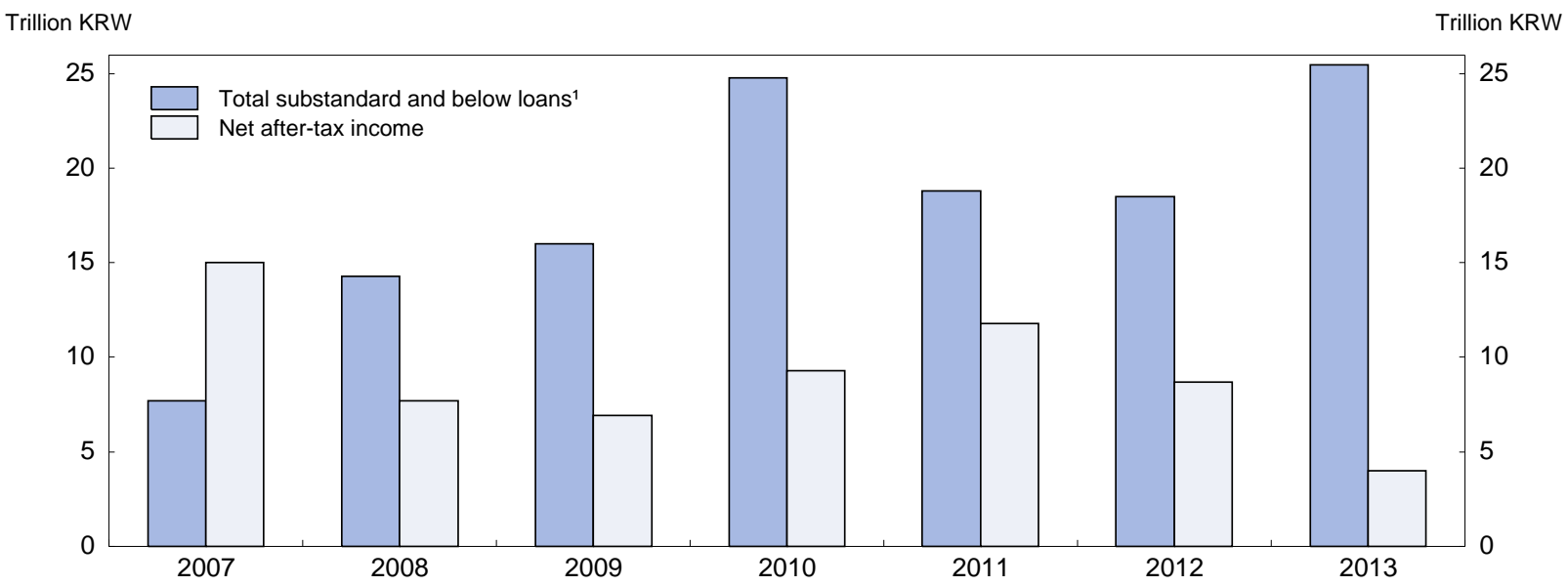

1. Includes loans classified as substandard, doubtful and presumed loss as a share of total loans. Source: FSS (2013a and 2013c).

53. Given that household debt will remain high for some time to come, it is important to expand financial institutions' reserves to absorb the potential loss from delinquent household debt. In the short term, financial institutions should take a prudent approach to paying dividends and salaries to management and employees in order to retain profits. In addition, the implementation of Basel III from December 2013 will enhance financial institutions' capacity to absorb losses by limiting the distribution of dividends and the repurchase of financial institutions' own shares when bank holding companies fail to maintain the minimum capital buffer of $2.5 \%$. In the longer term, it is important to boost bank profitability from its traditionally low level.

\section{Financial support for the poor risks creating moral hazard}

54. Given the difficulty of market-based lending to meet the financial demands of households with low income and credit ratings, there is considerable pressure on the government to fulfill this role through the preferential programmes, such as Miso Finance and the Sunshine Loan discussed above. Indeed, financial support to people with low income and credit ratings has increased remarkably since the global financial crisis. Between 2008 and November 2013, 12.7 trillion KRW (1.0\% of 2012 GDP) has been provided to assist nearly 1.4 million people through the four major preferential loan programmes (Table 11). The number of people that participated in these programmes amounted to $60 \%$ of the number of 
delinquent borrowers in 2008 (Figure 9). In addition, 970 thousand delinquent borrowers have been assisted by the restructuring of 20.9 trillion KRW of household debt since 2008 (Table 12). ${ }^{12}$ Such public assistance helped reduce the number of delinquent borrowers from 2.6 million at the end of 2007 to 1.1 million at the end of 2013 (Figure 9).

Table 11. Government support in the four major preferential loan programmes

Billion KRW and number of persons (in parentheses)

\begin{tabular}{|l|c|c|c|c|c|c|}
\hline \multicolumn{1}{|c|}{ Programme $^{\mathbf{1}}$} & $\mathbf{2 0 0 9}$ & $\mathbf{2 0 1 0}$ & $\mathbf{2 0 1 1}$ & $\mathbf{2 0 1 2}$ & $\mathbf{2 0 1 3}^{\mathbf{2}}$ & Total \\
\hline $\begin{array}{l}\text { Miso Finance } \\
\text { (July 2008) }\end{array}$ & $\begin{array}{c}61.2 \\
(15815)\end{array}$ & $\begin{array}{c}114.4 \\
(15192)\end{array}$ & $\begin{array}{c}310.7 \\
(28022)\end{array}$ & $\begin{array}{c}274.6 \\
(29542)\end{array}$ & $\begin{array}{c}241.8 \\
(29191)\end{array}$ & $\begin{array}{c}1002.7 \\
(117762)\end{array}$ \\
\hline $\begin{array}{l}\text { Sunshine Loan } \\
\text { (July 2010) }\end{array}$ & - & $\begin{array}{c}1385.9 \\
(152731)\end{array}$ & $\begin{array}{c}483.5 \\
(56097)\end{array}$ & $\begin{array}{c}610.9 \\
(71130)\end{array}$ & $\begin{array}{c}1783.0 \\
(198578)\end{array}$ & $\begin{array}{c}4263.3 \\
(478536)\end{array}$ \\
\hline $\begin{array}{l}\text { New Hope Seed } \\
\text { Loan }\end{array}$ & - & $\begin{array}{c}267.7 \\
(33546)\end{array}$ & $\begin{array}{c}1365.0 \\
(156550)\end{array}$ & $\begin{array}{c}1987.4 \\
(215188)\end{array}$ & $\begin{array}{c}1727.7 \\
(172239)\end{array}$ & $\begin{array}{c}5347.8 \\
(577523)\end{array}$ \\
\hline $\begin{array}{l}\text { Switch-Over } \\
\text { Dream Loan } \\
\text { (December 2008) }\end{array}$ & $\begin{array}{c}143.1 \\
(14936)\end{array}$ & $\begin{array}{c}168.5 \\
(16569)\end{array}$ & $\begin{array}{c}475.2 \\
(46164)\end{array}$ & $\begin{array}{c}672.7 \\
(62734)\end{array}$ & $\begin{array}{c}599.0 \\
(55125)\end{array}$ & $\begin{array}{c}2058.5 \\
(195528)\end{array}$ \\
\hline Total & $\begin{array}{c}194.3 \\
(30751)\end{array}$ & $(218038)$ & $\begin{array}{c}2634.4 \\
(286833)\end{array}$ & $\begin{array}{c}3545.6 \\
(378594)\end{array}$ & $\begin{array}{c}4351.5 \\
(455133)\end{array}$ & $\begin{array}{c}12672.3 \\
(1369349)\end{array}$ \\
\hline
\end{tabular}

1 The progamme starting date is shown in parentheses.

2. As of end-November 2013.

Source: Financial Services Commission.

Table 12. Government support for the credit recovery of borrowers

Brillion KRW and number of persons (in parentheses)

\begin{tabular}{|l|c|c|c|c|c|c|c|}
\hline & $\mathbf{2 0 0 8}$ & $\mathbf{2 0 0 9}$ & $\mathbf{2 0 1 0}$ & $\mathbf{2 0 1 1}$ & $\mathbf{2 0 1 2}$ & $\mathbf{2 0 1 3}^{\mathbf{1}}$ & Total \\
\hline Individual & 2239.4 & 2720.8 & 2626.7 & 2775.5 & 2372.1 & 2258.8 & 14994.3 \\
workouts & $(73264)$ & $(86452)$ & $(72297)$ & $(71655)$ & $(65154)$ & $(65899)$ & $(348269)$ \\
\hline Pre-Workout & - & 205.4 & 165.7 & 348.9 & 434.5 & 515.0 & 1669.5 \\
(April 2009) & & $(6950)$ & $(6230)$ & $(13217)$ & $(16599)$ & $(18679)$ & $(61676)$ \\
\hline National & 20.5 & 307.2 & 501.2 & 459.2 & 425.5 & 2543.8 & 4257.4 \\
Happiness Fund $^{2}$ & $(14296)$ & $(61744)$ & $(89370)$ & $(78125)$ & $(82288)$ & $(234543)$ & $(560366)$ \\
\hline Total & 2259.9 & 3234.4 & 3293.6 & 3.6 & 2684.7 & 5317.6 & 20921.2 \\
& $(87560)$ & $(155146)$ & $(167898)$ & $(162997)$ & $(136357)$ & $(319121)$ & $(970311)$ \\
\hline
\end{tabular}

1. As of end-November 2013.

2. Including the Credit Recovery Fund.

Source: Financial Services Commission.

55. However, the financial support programmes create moral hazard for both the borrowers and lenders. Public financial support is sometimes regarded as transfers that do not need to be serviced. In addition, the management structure of the current preferential programmes appears to be ineffective in preventing moral hazard. While most of the financing is provided by the government or by voluntary

12. In comparison, between 2002 and 2007, when there were massive defaults of household debt due to the collapse of the credit card bubble, 660 thousand people received credit recovery assistance under the individual workouts. 
contributions, the Sunshine Loan programme and Miso Finance are run by third parties. Therefore, in the absence of appropriate monitoring and supervision, the operator tends to be more generous in lending and less sensitive to the risk of default compared with financial institutions that make loans on a commercial basis with their own resources. The moral hazard problem can be seen in the marked rise in the delinquency ratios of Sunshine Loan and Miso Finance programmes, even though they charge very low interest rates, thereby making the debt service burden much smaller than for ordinary loans made on a commercial basis by financial institutions (Figure 16). Indeed, the delinquency rate for Sunshine Loans reached $10 \%$ only three years after its launch in 2010, three times higher than for New Hope Seed Loans, which are run by the banks themselves. In sum, overly generous programmes send the message that the loans are a gift.

56. The size of the funds backing the major programmes appears large enough to absorb the loss in the short run: Miso Finance can be maintained if its outstanding loans are limited to 300 billion KRW (about \$289 million), while the Sunshine Loan programme assumes that $20 \%$ of credit guarantees will fall into default. Nevertheless, the sharp rise in delinquency for each of the four programmes raises doubts about their long-run sustainability.

57. To ensure their long-run sustainability and reduce moral hazard problems, these programmes should be redesigned. At the very least, the assistance to households with low income and credit ratings should not be regarded as free money by debtors. The programme operators should limit loans, based on proper evaluation, to those who have the ability and intention to service their debt. Even though the programmes do not seek to earn profits, they should be run so as to maintain the fund's capital with a view to sustaining the programmes in the long term and avoiding the need for additional funds. The operator, who is generally a third party, should bear in mind that additional fund raising in order to cover up the loss should be minimised in the future and be aware of their responsibility to maintain programmes for a significant period. Appropriate supervision by the government and other providers of funds should be encouraged as well.

Figure 16. The delinquency rate of preferential loan programmes is rising

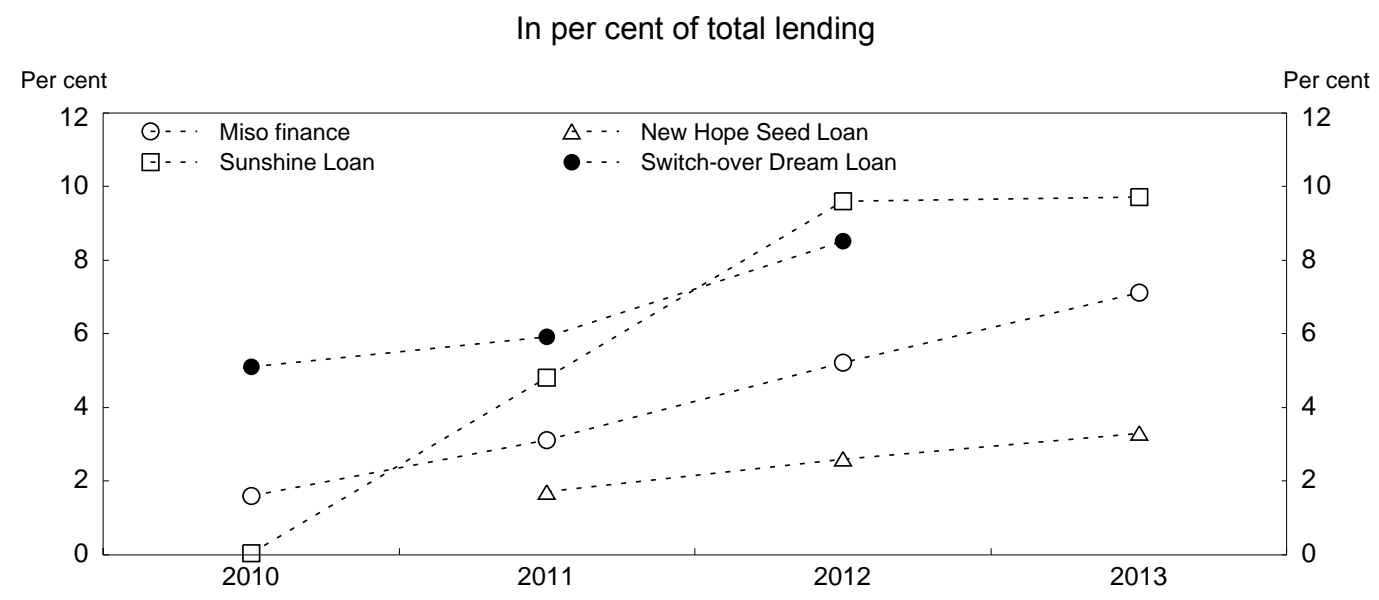

Source: FSC (2012) and data submitted by the FSC.

58. In particular, the large-scale write-offs of up to $70 \%$ of existing debt, including interest and principal, through the National Happiness Fund also create concern about moral hazard. This risk is especially large at present, given the priority attached to social cohesion in the national agenda and the expansion of government programmes to support low-income households. As noted above, the government had consistently refused to write off principal under private debt restructuring programmes in order to limit 
moral hazard, but changed its position in 2013 with the introduction of the National Happiness Fund (Box 3). To reduce this risk, the government has stated that the NHF will be the final opportunity for debt write-offs. However, it is questionable whether debtors will believe the government, given the increasing emphasis on social cohesion and social spending. Strictly enforcing the rules attached to current programmes may help limit moral hazard.

\section{Other problems with the preferential loan programmes}

59. In addition, there are a number of criticisms of such programmes. First, the temporary benefits to individuals with low income and credit ratings do not help them to become autonomous. According to the Credit Counselling and Recovery Service, about $30 \%$ of the 1 million people who have received credit recovery support since 2003 have failed to fulfil their debt restructuring programme and have thus fallen into default again. While financial support can temporarily relieve the debt burden of delinquent borrowers, their economic and financial condition cannot be improved without stable income.

60. Second, public support may exacerbate the financial situation of persons with low income and credit ratings by expanding their debt. Without a stable job or income, it is impossible for many debtors to service their debt even under the preferential loan programmes. For many in this group, it would be preferable to meet their needs through social safety programmes rather than providing additional loans. Beneficiaries of the preferential loan programmes who are unable to service their debt even with belowmarket interest rates should instead be protected by the social safety net. Therefore, it is essential to further relax the eligibility conditions for the Basic Livelihood Security Programme, the main pillar of the social safety net, which currently covers only 3\% of the population (2014 OECD Economic Survey of Korea). The tax-benefit system also needs to improve work incentives, in part by expanding the earned income tax credit. At the same time, it is important to expand job training and labour activation programmes. An expanded social safety net would better address the needs of many low-income households, while preventing an additional run-up in their debt.

61. Third, preferential government loans hinder the development of financial services for households with low income and credit ratings as the public programmes directly compete or overlap with the traditional players in this market, such as mutual saving banks and mutual credit institutions. Increased government intervention causes a crowding-out effect as financial institutions focus on offering preferential loans, which generate stable income at low risk thanks to public credit guarantees, instead of their own commercial loans. This limits their accumulation of market knowledge and thus their capacity to lend to households with low income and credit ratings, while exacerbating the financial problems of such households in the long run.

62. The long-run objective should be to reduce the government role and develop a market-based system to provide credit to individuals with low income and credit ratings. Such a system depends on financial institutions gaining experience in lending to such individuals and enhancing its credit-rating capacity for disadvantaged borrowers. Given that banks have little interest in lending to individuals with low income and poor credit ratings, the role of small non-bank financial institutions, such as mutual saving banks and mutual credit institutions, should be encouraged. This would reduce the role of finance companies, which charge substantially higher interest rates on household loans. In this regard, the Sunshine Loans seem appropriate because the government encourages lending to individuals with low income and credit ratings by risk-sharing with financial institutions through credit guarantees and provides loans via non-bank financial institutions, such as mutual saving banks. However, the risk-sharing arrangement makes the government bear $95 \%$ of the loss, a share that is too high to properly develop the market. The credit guarantee ratio, therefore, should be reduced or at least differentiated according to the characteristics of the borrower. 


\section{Promoting responsible lending by financial institutions and financial education for consumers}

63. It is important to enhance both consumer financial protection and the responsibility of financial institutions to avoid excessive lending. While debtors are responsible for servicing their debt, financial institutions, which make loans on the basis of their credit evaluation also bear responsibility when debtors default. Lenders must avoid making loans that are excessive relative to the borrowers' ability to service their debt. During asset price booms, lenders tend to expand loans, reflecting their short-term incentives, without proper evaluation, even though it can be harmful to them in the long run. In the early $2000 \mathrm{~s}$, for example, credit card companies aggressively expanded their credit supply in the context of strong competition between companies for market share, while proper risk management and consumer protection were weakened (KIF, 2013). In particular, they issued large numbers of credit cards to persons with low credit ratings without proper credit evaluation. Once the credit card holders fell into default, they faced severe debt collection measures by financial institutions, including measures that were illegal and caused social disruption. This episode illustrates the importance of prohibiting excessive lending, although this is difficult to impose by law due to the vagueness of the concept. However, it should be emphasized through prudential supervision and voluntary measures, such as best practices and internal guidelines for financial institutions.

64. In addition, debt-collection measures that impose excessive and unfair burdens on debtors should be strictly forbidden. Given the social emphasis on the credibility and responsibility of debtors, Korea has placed few restrictions on debt collection activities. For example, parents were requested to pay their children's debt and vice versa when the credit card bubble burst. Debt collectors made phone calls at any time of the day and as often as they liked, thus disrupting the life of debtors. Such methods created considerable social anxiety, leading to regulations on debt collection activities to protect debtors. Nevertheless, there are still some lenders and debt collectors who violate these regulations, creating social problems. It is important, therefore, to further ensure protection of debtors.

65. Financial education for consumers should also be expanded. Before borrowing money, households should carefully examine whether they can service the debt and also if there are alternatives to loans, such as social welfare programmes. Given that many persons with low income have limited knowledge of such issues, measures by the government or non-profit organisations are necessary. The OECD is taking the lead on promoting consumer financial protection through its International Network on Financial Education, which published guidelines in this area in 2012 (OECD, 2012c). 


\section{Box 4. Summary of recommendations to address the household debt problem}

Slow the growth of household debt and reduce it as a share of household income

- $\quad$ Achieve a "soft landing" in the household debt ratio, while avoiding a significant fall in household debt that would have an adverse effect on output growth.

- Slow the growth of household debt through financial supervision, supplementing the usual numerical measures of financial institutions' soundness with behavioural information.

- Boost output growth through the government's initiative to promote a creative economy and other reforms.

- Co-ordinate other policies influencing household debt, such as tax and housing policies, with financial supervision.

\section{Enhance the capability of banks to withstand risks associated with household debt}

- Further boost financial institutions' reserves to increase their capacity to absorb potential losses from household debt, while raising bank profitability in the long run.

Reducing the risk associated with household loans stemming from the housing market

- Further increase the share of mortgages that are based on fixed interest rates and instalment loans, in part by introducing covered bonds.

- $\quad$ Allow financial institutions more flexibility in applying the relatively strict loan-to-value ratio.

- Reform the comprehensive landholding tax, while raising the overall tax burden on property holdings.

Develop market-based lending to households with low income and credit ratings

- $\quad$ Avoid preferential loan programmes that crowd out market-based lending.

- $\quad$ Promote the development of lending by local non-bank financial institutions to disadvantaged households that are credit-worthy.

\section{Improve preferential loan programmes for disadvantaged households}

- Ensure the long-run viability of such programmes by granting loans only to those who are capable and willing to service their loans, thereby preserving the capital of the programmes.

- Operate the programmes in a way so as to achieve the long-run goal of reducing household debt and developing the role of market-based credit for disadvantaged households.

- Expand the social safety net to meet the needs of low-income households and reducing their reliance on preferential loan programmes, which further expand their debt.

Minimise moral hazard while strengthening financial consumer protection

- Avoid additional programmes offering large write-offs of principal and interest so as to avoid moral hazard

- Discourage excessive lending to households by financial institutions through appropriate prudential supervision and promote financial education for households to prevent over-borrowing. 


\section{Bibliography}

Bank of Korea (2013a), Financial Stability Report, April, Seoul.

Bank of Korea (2013b), Household Credit during the Fourth quarter of 2013 (Preliminary), Seoul (in Korean).

Bank of Korea (2013c), 2012 Survey on Household Finance and Welfare (Additional Survey), Seoul (in Korean).

Chosun Ilbo (2013), Mortgage Loans of Around 100 Trillion KRW Will Be Due Next Year, 29 August 2013 (in Korean).

Debelle, G. (2004), "Macroeconomic Implications of Rising Household Debt”, BIS Working Papers, No. 153, Basel.

Financial Services Commission (2010), The Plan for Sunshine Loan Program, Seoul (in Korean).

Financial Services Commission (2011), Current Situation of Financial Support Programs for People with Low Income and Credit Ratings and the Plan for the Future, Seoul (in Korean).

Financial Services Commission (2012), The Outcome of Financial Support Programs for the People with Low Income and Credit Ratings and the Plan for the Future, Seoul (in Korean).

Financial Services Commission (2013), The Result of Individual Application for the National Happiness Fund and the Plan for the Future, Seoul (in Korean).

Financial Services Commission and Financial Supervisory Service (2011), The Comprehensive Policy Measures to Induce a Soft-landing of Household Debt, Seoul (in Korean).

Financial Services Commission, Ministry of Agriculture, Food and Rural Affairs, Ministry of Security and Public Administration and Financial Supervisory Service (2012), Complementary Policy Measures for Household Loans of Non-Bank Financial Institutions, Seoul (in Korean).

Financial Supervisory Service (2013a), Bank Earnings, 2013, Seoul.

Financial Supervisory Service (2013b), Domestic Banks' BIS Capital Ratios, September 2013, Seoul.

Financial Supervisory Service (2013c), Domestic Banks’SBLs, 2013, Seoul.

Financial Supervisory Service (2013d), Survey on Consumer Finance Companies Users, Seoul (in Korean).

Financial Supervisory Service (2014), The Outcome of Policy to Improve the Structure of Mortgage Loans by Banks, Seoul (in Korean).

Hwang, S. and W. Jung (2013), "Analysis on the Economic Behaviour of Household in Deficit", BOK Economic Review, No. 2013-11, Bank of Korea, Seoul (in Korean).

International Monetary Fund (2012), "Chapter 3. Dealing with Household Debt", World Economic Outlook, April.

Kim, J. (2012), "Financial Repression and Housing Investment: An Analysis of the Korean Chonsei", Munich Personal RePec Archive No. 47586. 
Kim, Y. and J. Lim (2013), "Stress Test on Financial Institutions against Shocks like Housing Price Drop: On the Base of 2012 Household Finance and Welfare Survey", Financial VIP Series, No. 2013-03, Korea Institute of Finance, Seoul (in Korean).

Kim, H., J. Sohn, D. Lee, H. Lim, and S. Nah (2013), "Analysis on the Causes of the Household Debt Increase in Korea and Its Sustainability", BOK Economic Review, No. 2013-4, Bank of Korea, Seoul (in Korean).

Korea Institute of Finance (2013), "White Paper on Household Debt", Financial Report, 2013-01, Seoul (in Korean).

Lee. K (2010), "Finance for the People with Low Income and Credit Ratings and Financial System: Medium and Long-Term Policy Tasks for Enhancing the Credit Supply for the People with Low Income and Credit Ratings", Korea Institute of Finance, Seoul (in Korean).

Ministry of Land, Infrastructure and Transport (2013), Housing Transaction Trend in December 2012, Seoul (in Korean).

Moody's (2013), “Korean Banks Resilient to High Household Debt Defaults”, Global Credit Research, October.

Na, S., C. Jeong, and J. Lim (2013), "The Structural Constraints on Consumption and Policy Implications", BOK Economic Review, No. 2013-4, Bank of Korea, Seoul (in Korean).

Nam. J (2013), "Current Situation of Financial System for the People with Low Income and Credit Ratings and Measures to Facilitate it", Presented at the Conference jointly held by the Korea Institute of Finance and the Korea Economic Association, Seoul (in Korean).

OECD (2001), OECD Economic Survey of Korea 2001, OECD Publishing, Paris.

OECD (2007), OECD Economic Survey of Korea 2007, OECD Publishing, Paris.

OECD (2012a), "Debt and Macroeconomic Stability", OECD Economics Department Policy Notes, No. 16, January, OECD Publishing, Paris.

OECD (2012b), OECD Economic Survey of Korea 2012, OECD Publishing, Paris, http://dx.doi.org/10.1787/eco_surveys-kor-2012-en.

OECD (2012c), OECD/INFE High-level Principles on National Strategies for Financial Education, OECD Publishing, Paris.

OECD (2013), Strengthening Social Cohesion in Korea, OECD Publishing, Paris, http://dx.doi.org/10.1787/9789264188945-en.

OECD (2014), OECD Economic Survey of Korea, OECD Publishing, Paris.

Shin, D. (2013), "The Current Situation of Household Debt and Policy Recommendations", Economic Issue Analysis, No. 82, National Assembly Budget Office, Seoul (in Korean).

Statistics Korea, Bank of Korea and Financial Supervisory Service (2013), 2013 Survey on Household Finance and Welfare, Daejeon (in Korean).

The Economist (2014), "South Korea's housing market: Lumping it”, 15 February. 


\section{WORKING PAPERS}

The full series of Economics Department Working Papers can be consulted at www.oecd.org/eco/workingpapers

1163. Reducing the high rate of poverty among the elderly in Korea (September 2014) by Randall S. Jones and Satoshi Urasawa

1162. Promoting the financing of SMEs and start-ups in Korea (September 2014) by Randall S. Jones and Myungkyoo Kim

1161. Fostering inclusive growth by promoting structural change in the business sector. (September 2014) by Rauf Gönenç, Oliver Röhn, Vincent Koen and Fethi Ögünç.

1160. Reducing macroeconomic imbalances in Turkey

(September 2014) by Oliver Röhn, Rauf Gönenç, Vincent Koen and Evren Erdoğan Coşar.

1159. Reinvigorating the EU Single Market

(September 2014) by Jean-Marc Fournier.

1158. An exploration of the determinants of the subjective well-being of Americans during the great recession (August 2014) by Aida Caldera Sánchez and Caroline Tassot.

1157. Boosting the development of efficient SMEs in the Netherlands (September) by Rafał Kierzenkowski and Jochebed Kastaneer

1156. Making the banking sector more resilient and reducing household debt in the Netherlands (September 2014) by Rafał Kierzenkowski, Olena Havrylchyk and Pierre Beynet

1155. US long term interest rates and capital flows to emerging economies (July 2014) by Eduardo Olaberria

1154. Productivity measurement with natural capital and bad outputs (July 2014) by Nicola Brandt, Paul Schreyer and Vera Zipperer

1153. Reducing income inequality and poverty and promoting social mobility in Korea (July 2014) by Randall S. Jones and Satoshi Urasawa

1152. Fostering a creative economy to drive Korean growth (July 2014) by Randall S. Jones and Myungkyoo Kim

1151. Economic uncertainties and their impact on activity in Greece compared with Ireland and Portugal

(July 2014) by Jan-David Schneider and Claude Giorno

1150. Workplace stress in the United States: issues and policies (July 2014) by Michael Darden

1149. Taxing the rent of non-renewable resource sectors: a theoretical note (July 2014) by Julien Daubanes and Saraly Andrade de Sá 
1148. Health, work and working conditions: a review of the European economic literature (July 2014) by Thomas Barnay

1147. Making the best of new energy resources in the United States (July 2014) by Douglas Sutherland

1146. Improving well-being in the United States (July 2014) by Aida Caldera Sánchez, Patrick Lenain and Sarah Fléche

1145. Deconstructing Canada's housing markets: finance, affordability and urban sprawl (July 2014) by Calista Cheung Restructurer les marchés canadiens du logement: financements, accessibilité financière et étalement urbain (Juillet 2014) par Calista Cheung

1144. Women's role in the Swiss economy

(July 2014) by Richard Dutu

Le rôle des femmes dans l'économie suisse (Juillet 2014) par Richard Dutu

1143. Overcoming skills shortages in Canada

(July 2014) by David Carey

Combler les pénuries de compétences au Canada

(Juillet 2014) par David Carey

1142. Trade patterns in the 2060 world economy

(July 2014) by Jean Chateau, Lionel Fontagné, Jean Fouré, Åsa Johansson and Eduardo Olaberria

1141. The Demand for Skills 1995-2008: A global chain perspective

(July 2014) by Bart Los, Marcel P. Timmer and Gaaitzen J. De Vries

1140. International migration: The relationship with economic and policy factors in the home and destination country

(July 2014) by Ben Westmore

1139. Gross earning inequalities in OECD countries and major non-member economies: determinants and future scenarios

(July 2014) by Henrik Braconier and Jenifer Valenzuela Ruiz

1137. Managerial capital and business $R \& D$ as enablers of productivity convergence (September 2014) by Dan Andrews and Ben Westmore

1136. Long-term patterns of trade and specialisation

(July 2014) by Asa Johansson and Eduardo Olaberria

1135. Consequences of climate change damages for economic growth $-a$ dynamic quantitative assessment

(July 2014) by Rob Dellink, Elisa Lanzi, Jean Chateau, Francesco Bosello, Ramiro Parrado and Kelly de Bruin 